
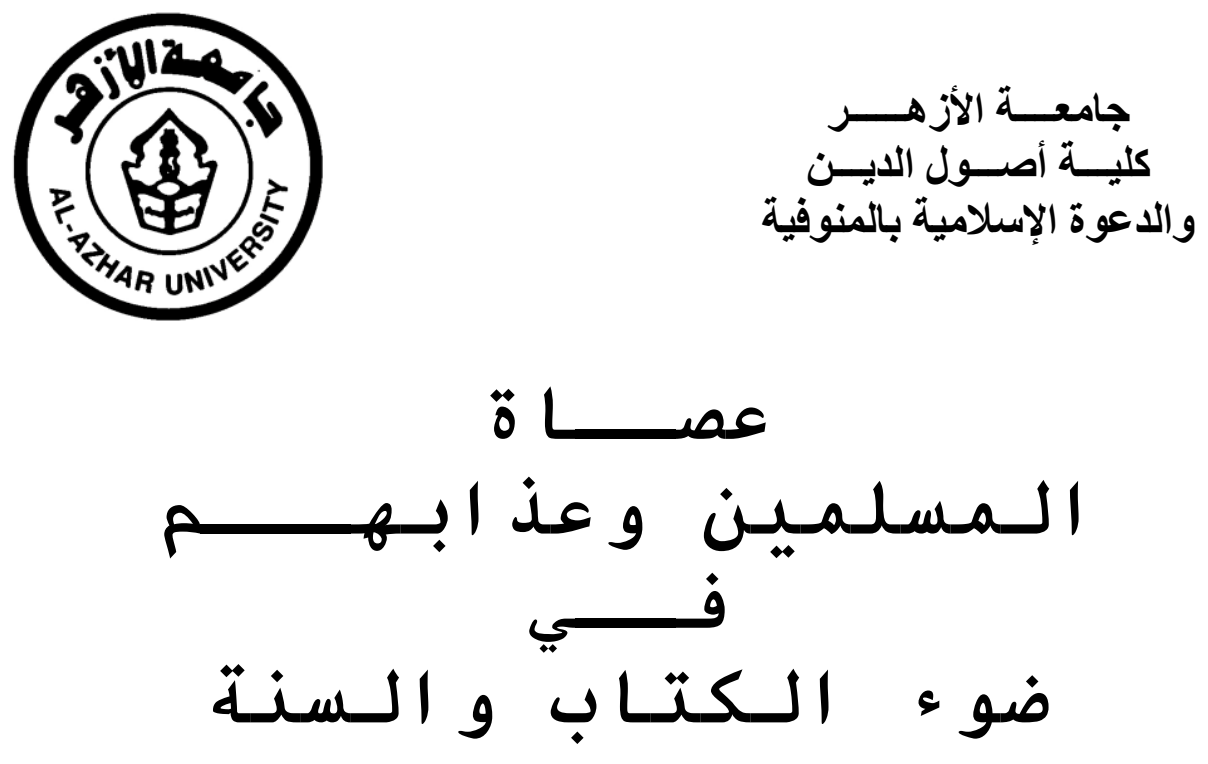

إعداد الدكثئر

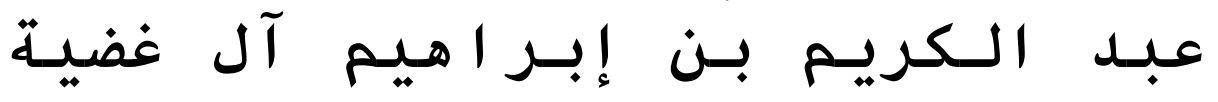
استاذ مساعد بكلية الحديث والدراساث الإسلامية

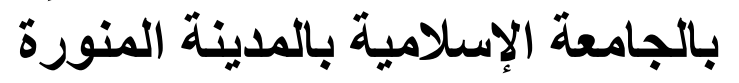
مسنبلة من من مانم

حولية كلية أصول الدين والدعوة بالمنوفية مدية

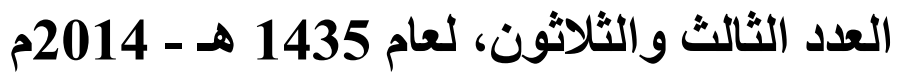

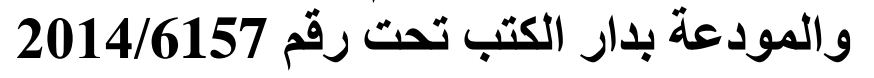

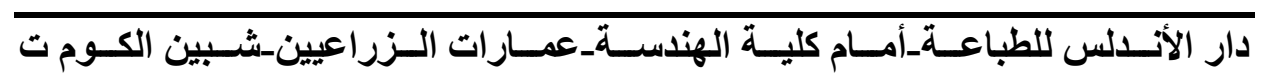
0482222090 


\section{ملخص البحثة}

رتبت هذا البحث على مقدمة وفصلين وخاتمة. الفصل الأول: عصاة المسلمين:

$$
\text { وفيه خمسة مباحث: الأش: }
$$

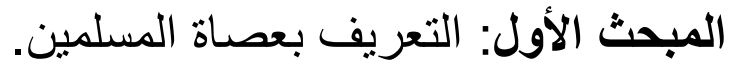

المبحث الثاني: أدلة عذاب عصداة المسلمين.

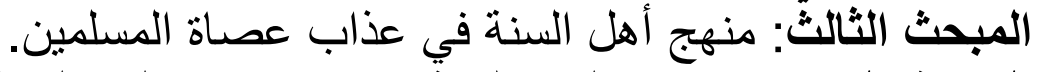

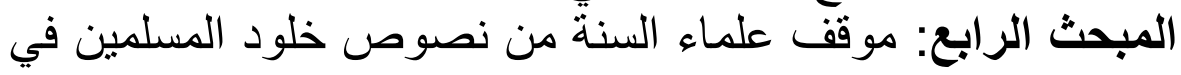

المبحث الخامس: بعض موانع إنفاذ وعيد الله لعصاة المسلمين.

الفصل الثاني: أنواع عذاب عصاة المئ المسلمين: وهي تنقسم إلى قسمين: أنواع: الأبن القسم الأول: في الانيا وهو الأنين: نوعان: النوع الأول: الأبتلاءات الأنيات ولعامة و والخاصة.

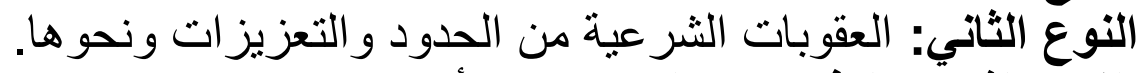

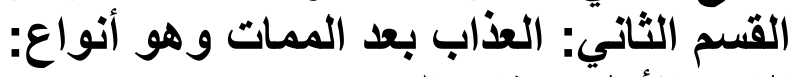

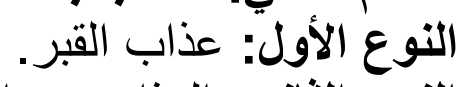
النوع الثاني: العذاب بعد البعث حتى يُقضى بين الفئ العباد.

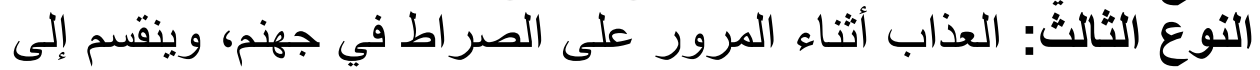

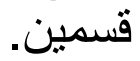
النوع الرابع: العذاب في جهنم.

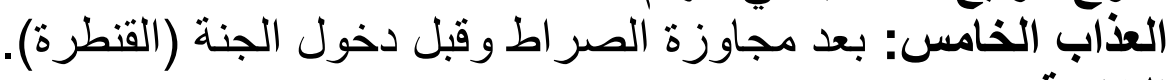
الخاتمة ثم مصادر ومراجع البحث

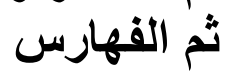




\section{بـ

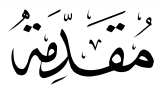

إنَّ الحَمَدَ لله نحمدُهُ ونستعينُهُ ونستغفره، ونعوذ بالله من شرور أنفسنا ومن من

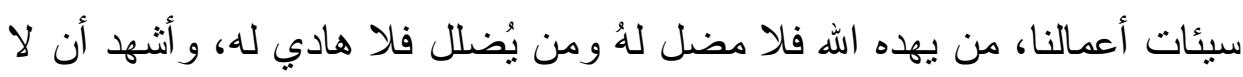

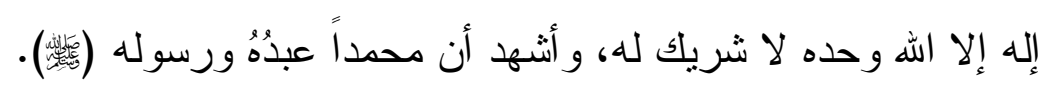

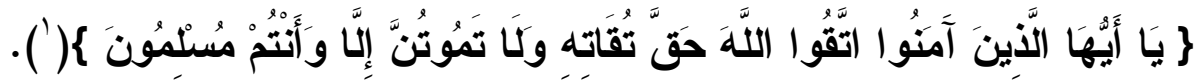

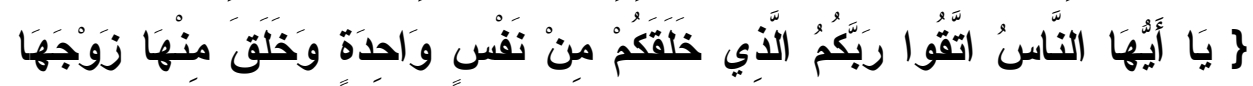

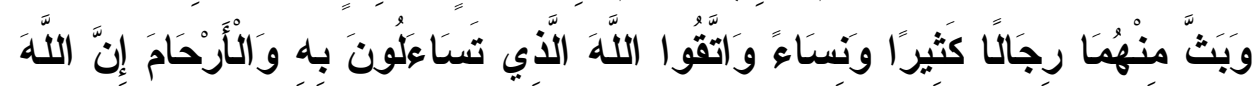

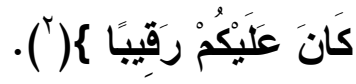

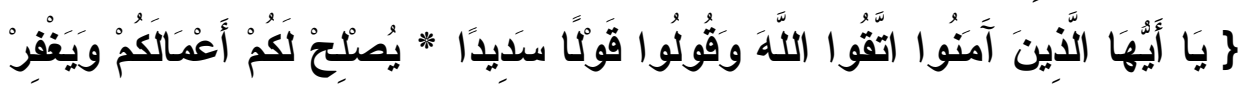

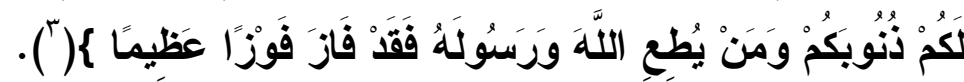

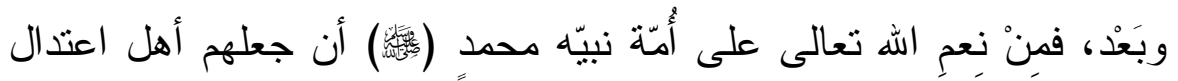

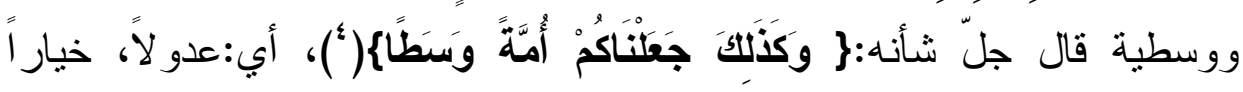
متوسطين بين طرف الإفراط -الغلو -، وطرف التفريط - التساهل - ، قال

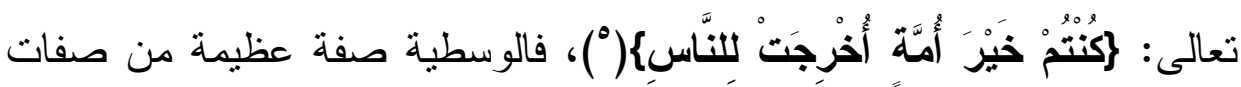
هذه الأمة المباركة لا نتمكلك عنها أبداً.

$$
\begin{aligned}
& \text { (1) [آل عمر ان: צ' 1)] } \\
& \text { (Y) [النساء: الاء 1) }
\end{aligned}
$$

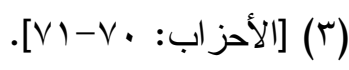

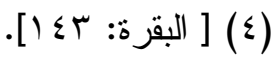

$$
\begin{aligned}
& \text { (0) [آل عمران: • • (1)] }
\end{aligned}
$$




\section{الدكتور/ عبد الكريم بن إبراهيم آل غضيد}

أمّا ما وجد من ظواهر تخالف ذلك؛ فإنه برجع إلى أسباب أخرى تتعلق

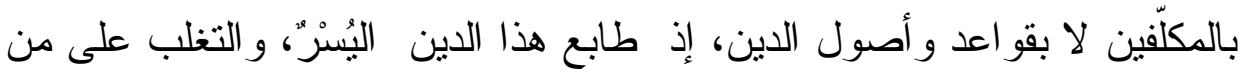

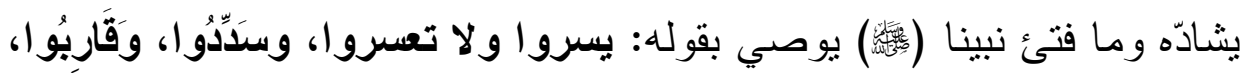
وبشَروا، وَأَبْثرُوا.

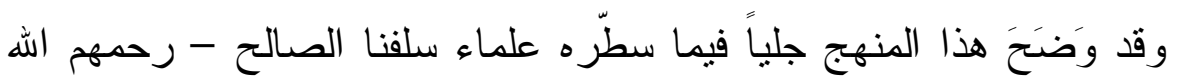
تعالى - في كتب خصّصوها لللك؛ وجعلو ا ميزة كل جزئية مما يعتقدونه:

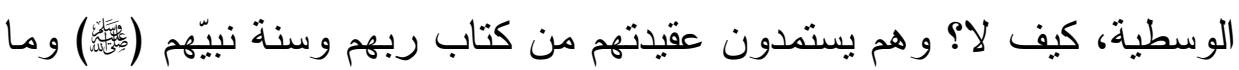
كان عليه الصحابة الكر ام رضي اله عنهم أجمعين.

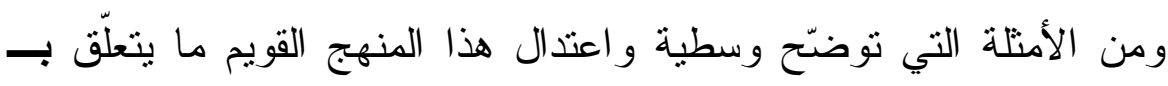

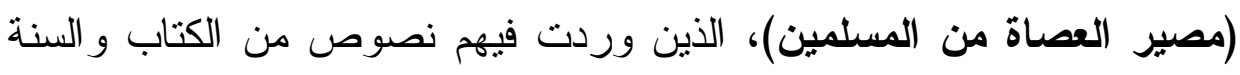

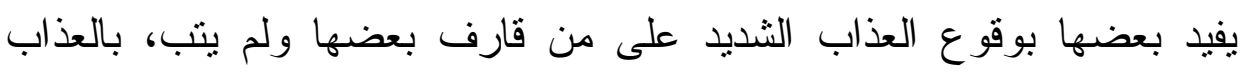

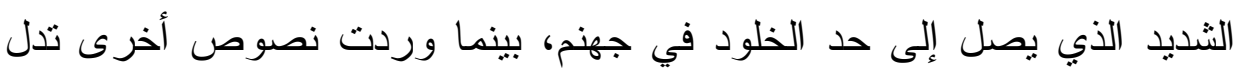

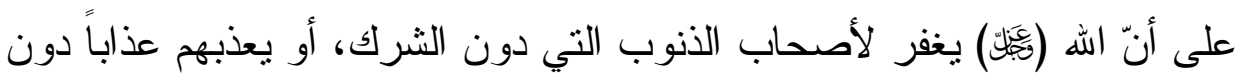
الحكم عليهم بالخلود في النار - أعاذنا الله منها - -. و هذه المسألة من الأهميّة بمكان، و العلم بالقول الحق فئل فيها أمر مهم ينبغي

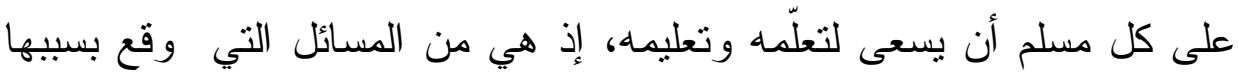

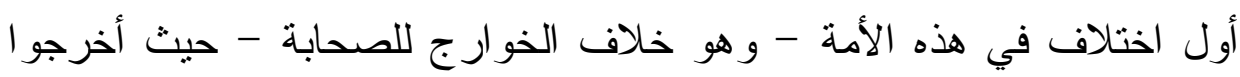

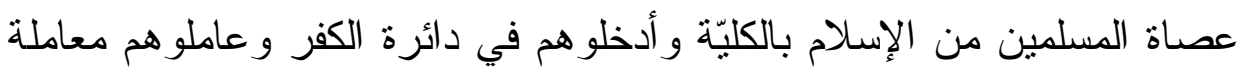
الكفار ، و استحلو ا بذلك دماء المسلمين و أمو الهم، و اله المستعان.

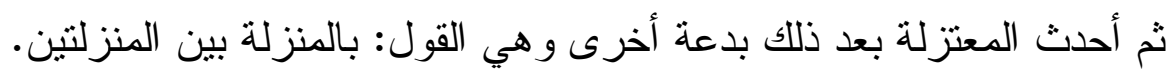

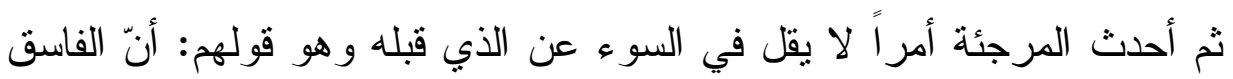

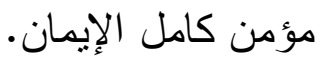


و لا تزال أمة الإسلام- في زماننا هذا - تعاني من تلك المشاكل،

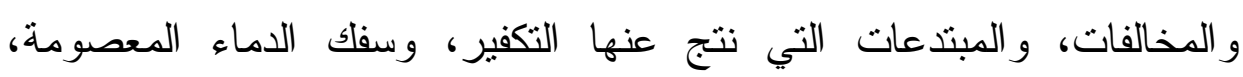

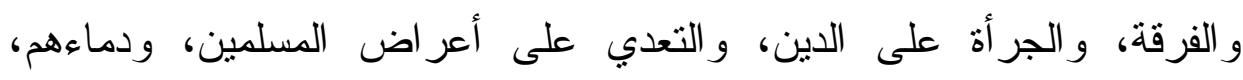
و عهودهم، ومو اثثقهم، وغير ذلك من المفاسد. و لا شك أنّ قلة مدارسة العقيدة الصافية الصحيحة بين الناس، وعدمة وعدم

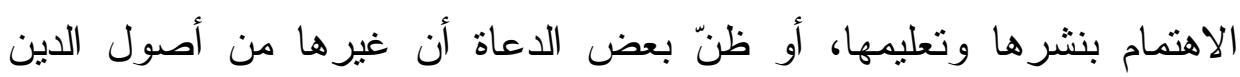

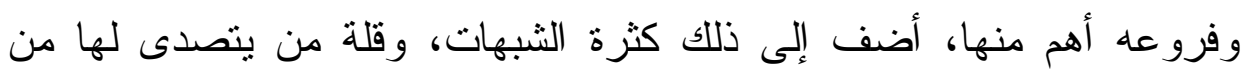
العلماء؛ كل ذلك كان سبباً بارزاً فيما نعانيه من فنتة التكفير و التعدي على الدماء

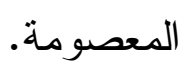

و لا أزعم أني جئت بجديد؛ غير أني جمعتها في مكان واحد، ورتبتها، و أتيت بدليل أو دليلين على كل جزئية من هذه المسألة، لأنني لو جمعت الأدلة

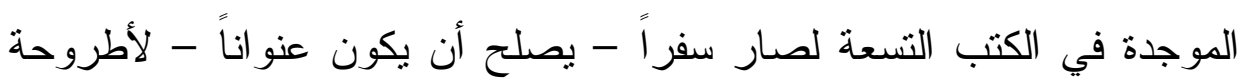

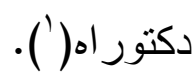

و أصرح من وققت عليه في جمعها وذكرها - لكن باختصار - الإمام

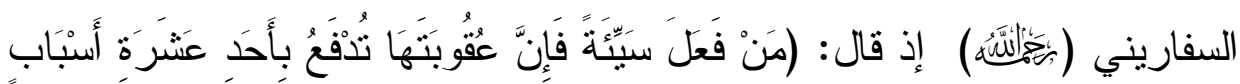

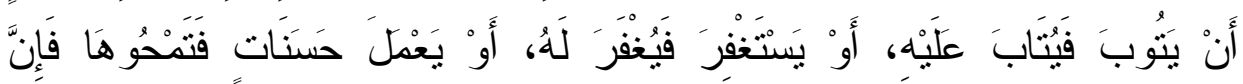

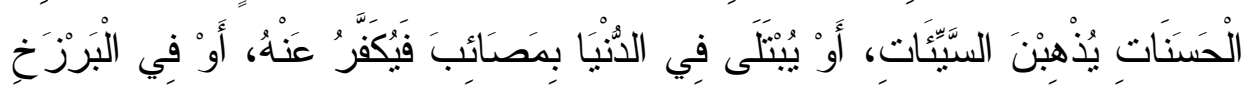

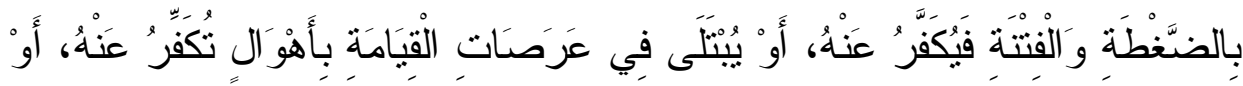

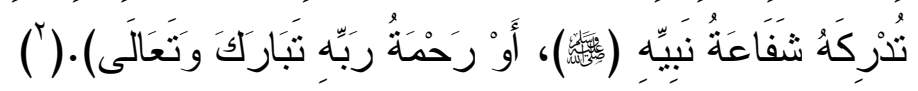

(1) وقد جمعت جلها لإخر اجها في كتاب مستقل إن شاء اله (قريباً).

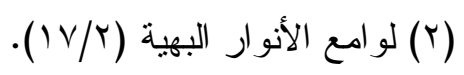


وقت رتبت هذا البحث على مقدمة وفصلين وخاتمة.

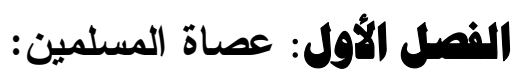
وفيه خمسة مباحث: الهبحث الأول: التعريف بعصاة المسلمين. الهبحث الثانه: أدلة عذاب عصاة المسلمين. الهبحث الثالث: منهج أهل السنة في عذاب عصاة المسلمين.

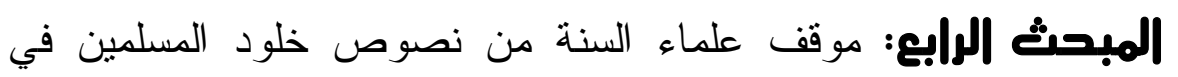
النار

الهبحث الخامسل: بعض مو انع إنفاذ و عيد اله لعصاة المسلمين. النصل الثاني: أنواع عذاب عصاة المسلمين: وهي تنقسم إلى قسمين: القسم الأول: في الانيا وهو نوعان: النوع الأول: الابتلاءات العامة و الخاصة. النوع الثاني: العقوبات الثرعية من الحدود و التعزيز ات ونحوها. القسم الثاني: العذاب بعد الممات وهو أنواع:

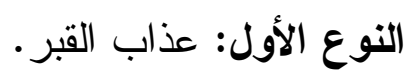
النوع الثاني: العذاب بعد البعث حتى يُقضى بين العباد. النوع الثالث: العذاب أثناء المرور على الصر اط في جهنم، وينقسم إلى قسمين. النوع الرابع: العذاب في جهنم. العذاب الخامس: بعد مجاوزة الصر اطو وقبل دخول الجنة (القنطرة). الخاتمة ثم مصادر ومر اجع البحث

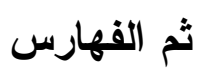




\section{عصاة السلمين وعدابهم في ضوي الكتاب والسنة}

وسيكون منهجي في هذا البحث كالتالي:

أولاً: أعزو الآيات القر آنية إلى موضعها في كتاب اللَّه (ثَّكَل)، بذكر السورة ورقم الآية.

ثانياً: أُخرّج الأحاديث الواردة في البحث، فما كان منها في الصحيحين أو أحدهما اكتفيت به، و إن كان في غير هما خرّجته، مع بيان درجته.

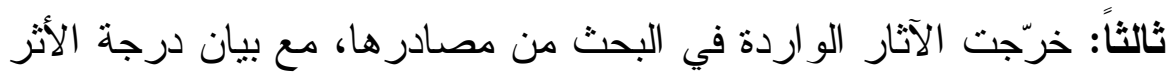
ما وجدت في ذلك نقلاً عن أهل هذا الفن. رابعاً: أذكر معاني الكلمات و الألفاظ الغريية الو اردة في البحث.

أسأل الله تعالى الإخلاص و العون و التوفيق و السداد، و أن يعيننا على ذكره، وشكر ه، وحسن عبادته.

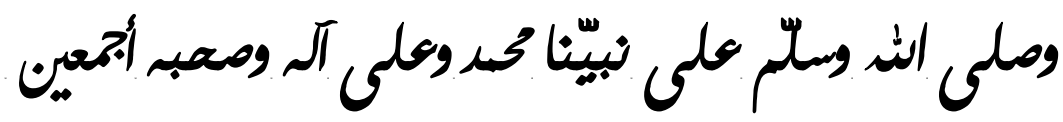


الدكتور/ عبد الكريم بن إبراهيم آل غضية

- $\Lambda$ - 


\section{الفمل الأول}

\section{عصاة المسلمين، وفيه عدة هباصث}

المبحث الأول: التعريف بعصاة المسلمين.

المبحث|الثاني: أدلة عذاب عصاة المسلمين.

الهبحث الثالث: منهج أهل السنة في عذاب عصاة المسلمين.

الهبحث الرابع: موقف علماء السنة من نصوص الخلود.

المبحث الخامس: موانع إنفاذ وعيد الله على عصاة

المسلمين. 
الدكتور/ عبد الكريم بن إبراهيم آل غضية

$-1 \cdot=$ 


\section{الببمث الأول \\ التعريف بـ (تصاة المسلمين)}

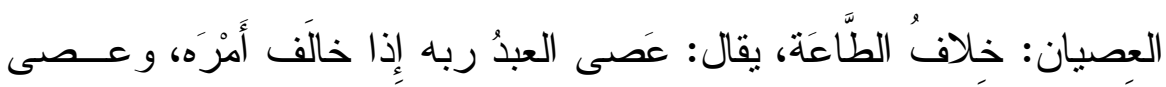

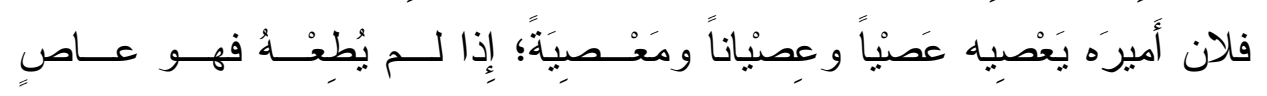

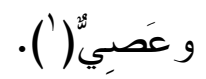

قال الر اغب: وعَصَى عصنيَّانَ: إذا خرج عن الطاعة، وأصله أن يتمنّع

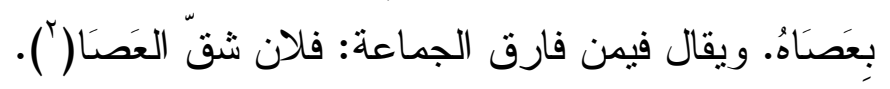

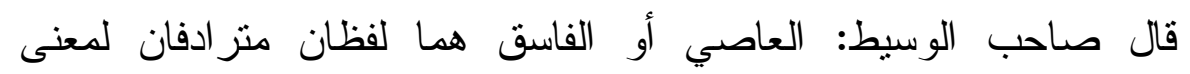

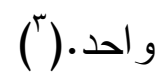

وقال الجرجاني: العصيان: هو نرك الانقياد.(")

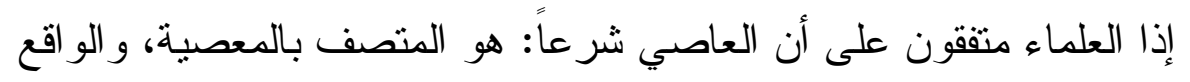

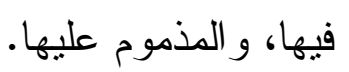

$$
\begin{aligned}
& \text { (1) لسان العرب (10/10) }
\end{aligned}
$$

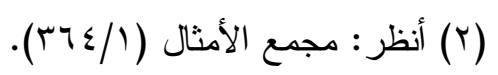

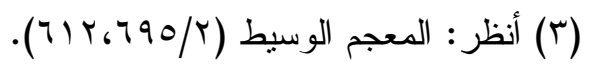

$$
\begin{aligned}
& \text { (ع) التعريفات (ص: (19) (1). }
\end{aligned}
$$




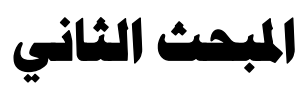 \\ أدلة عناب عصاة الإسلمينين}

دلت الأدلة من الكتاب العزيز و السنة المطهّرة على نوعدّ العاصين- عموماً

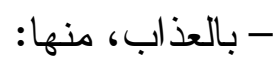

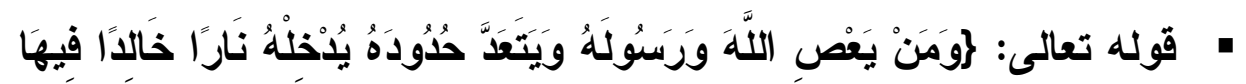

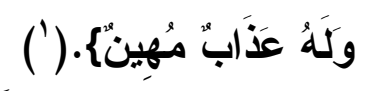

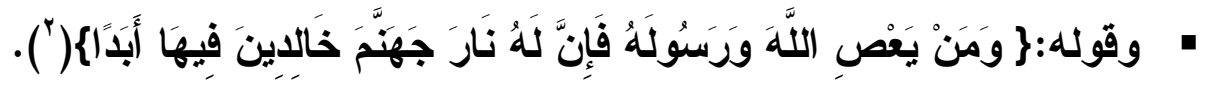

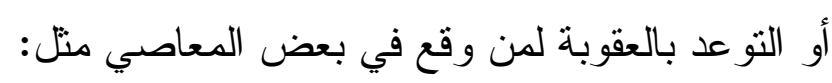

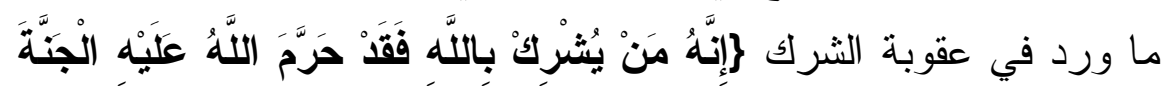

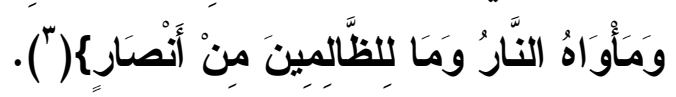

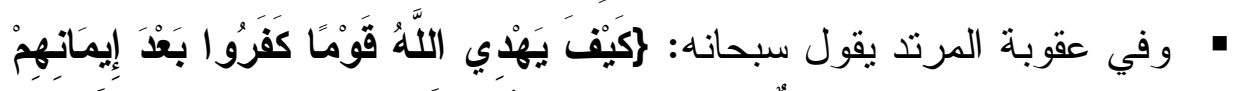

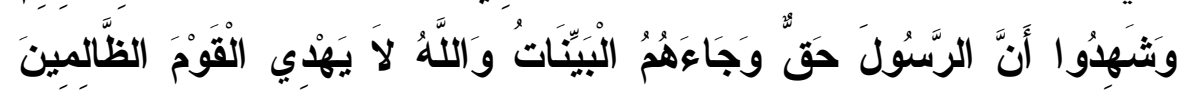

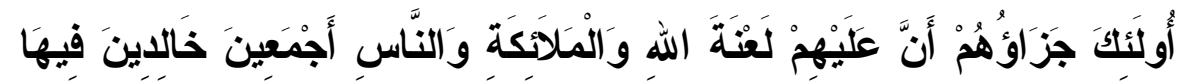

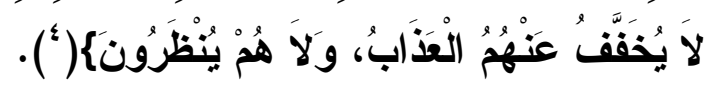

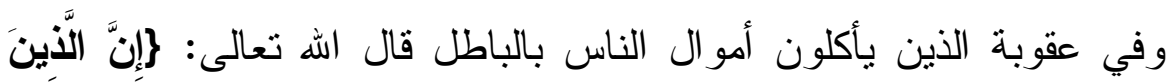

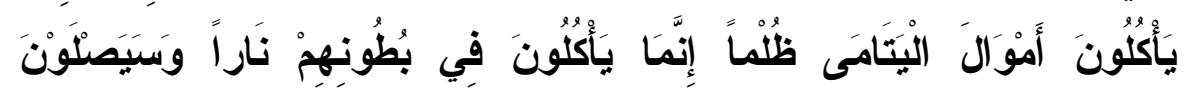

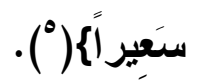

$$
\begin{aligned}
& \text { (1) [النساء: ؛ 1)] }
\end{aligned}
$$

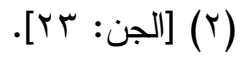

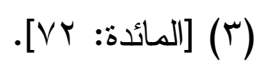

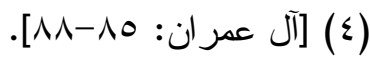

$$
\begin{aligned}
& \text {. }
\end{aligned}
$$


و عقوبة السرقة، وعقوبة الكذب، وعقوبة الإسبال...إلى غير ذلك مما يعد

من باب الكبائر (').

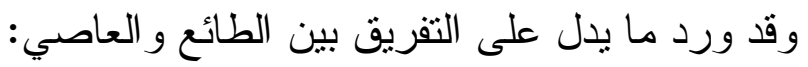

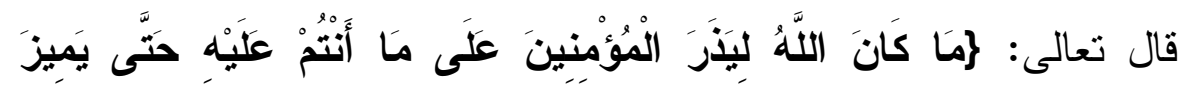

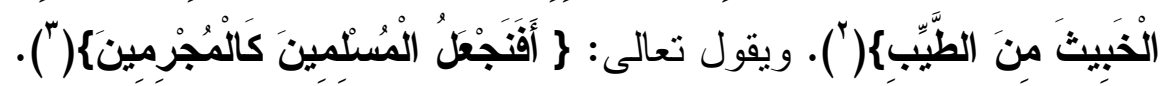

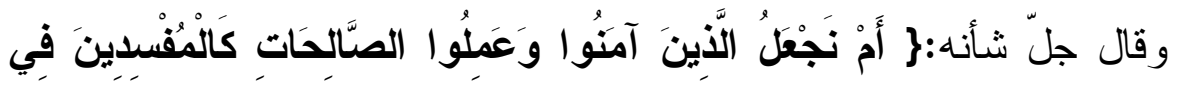

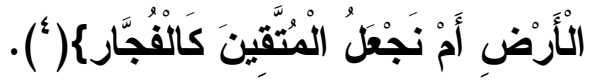

(1) و الكبيرة:كل ذنب نص على كبره، أو عظمه، أو نو عد عليه بالعقاب، أو علق عليه حد، أو شدد النكير عليه.

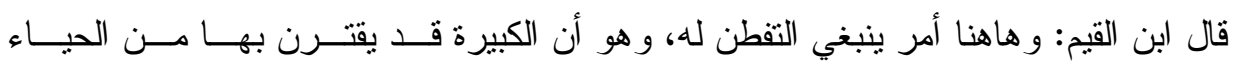

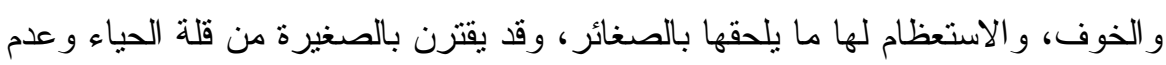

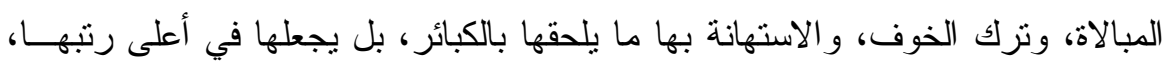

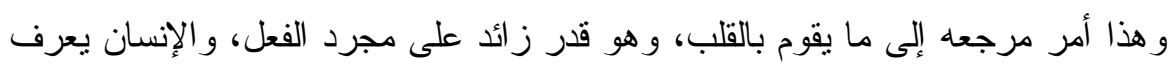

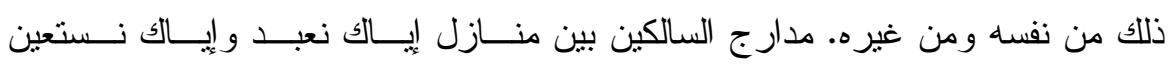

$$
\begin{aligned}
& \text {. (rN/l) } \\
& \text {. [ [ آل عمر ان: } \\
& \text { (ז) [القلم: هـr] } \\
& \text { ( ) [ص: }
\end{aligned}
$$




\section{المبحث الثالث}

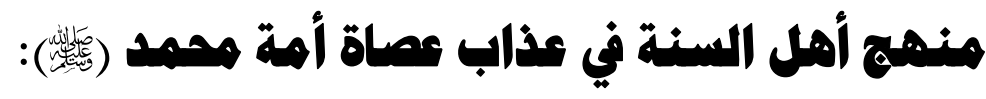

وكما مر بنا في معنى كلمة عاصي- في المبحث السابق- أنها يدخل في

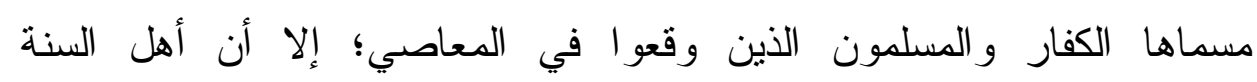

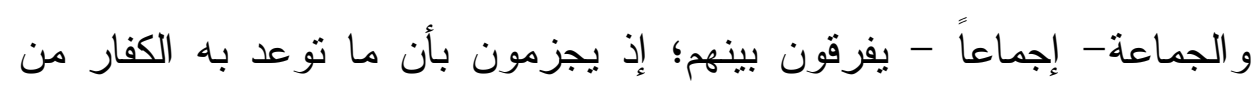
العذاب في جهنم: هو الخلود فيها. و أما عصاة المسلمين فلا يحكم عليهم بالكفر ، و لا بالخلود في النار، ولكن فئن

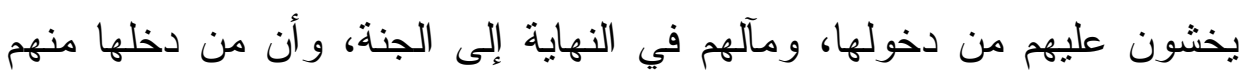

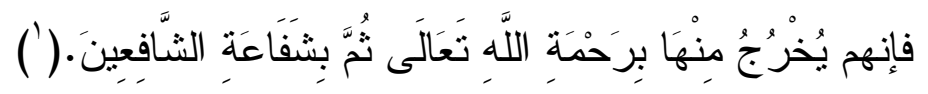




\section{البمث الرابع}

\section{هوقف علماد السنة من نصوص الخلوده:}

وقد وردت نصوص عدة في الكتاب و السنة - تقدم بعضها - تقهم أن هنالك أنو اعاً من العقوبات يستحق مقترفها (العاصي) الخلود في النار على رغم أنه لم

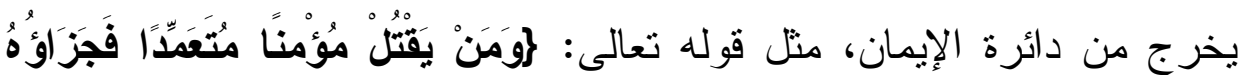

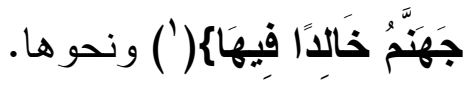

بينما وردت نصوص أخرى تُفيد أنّ المسلمين لا يَخلدون في النار مهما

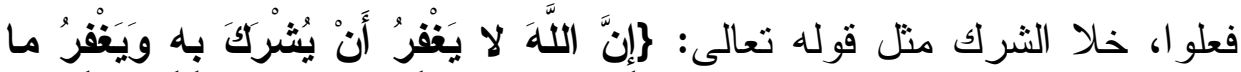

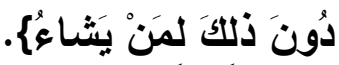

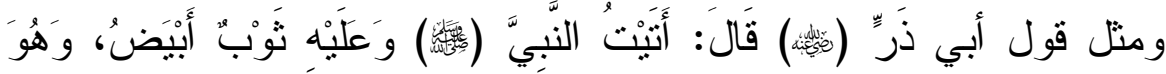

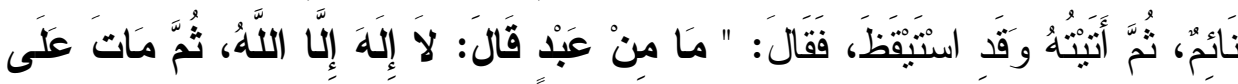

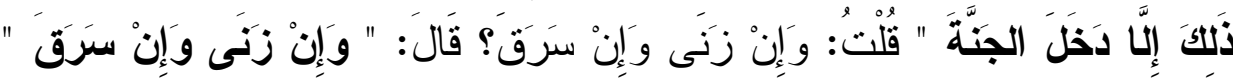

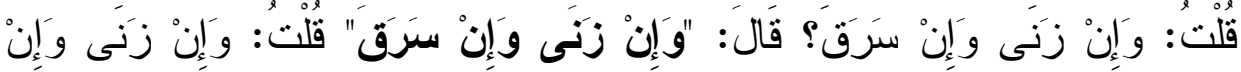

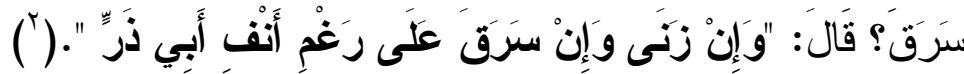

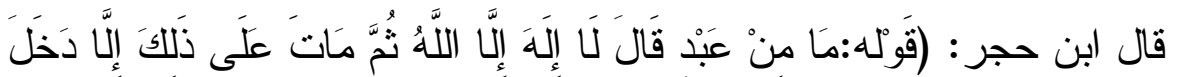

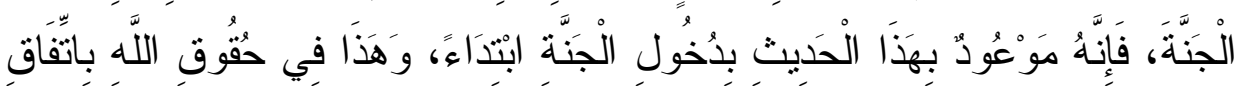

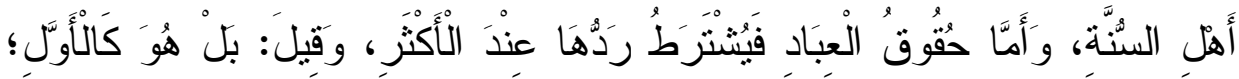

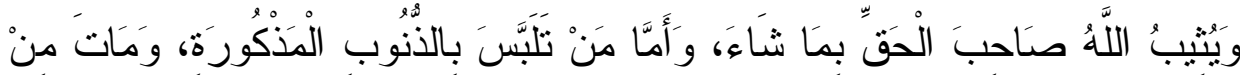

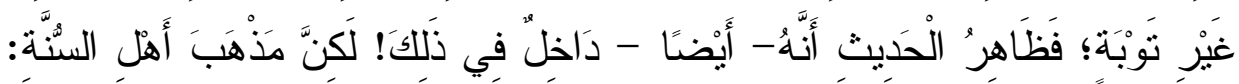

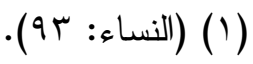

(Y) أخرجه البخاري، كتاب اللباس، باب الثياب البيض، حديث رقم (19 (ه). 


\section{الدكتور/ عبد الكريم بن إبراهيم آل غضية}

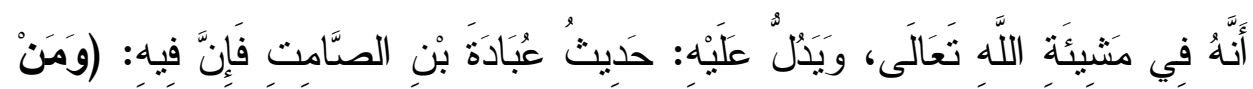

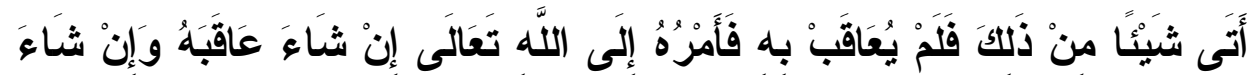

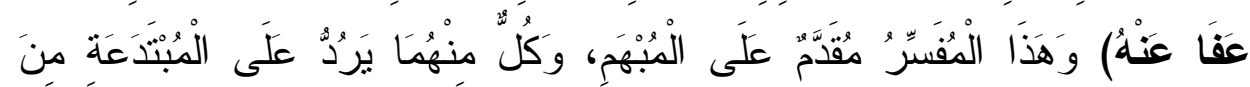

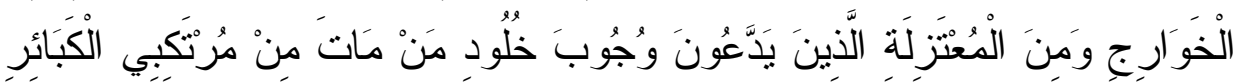

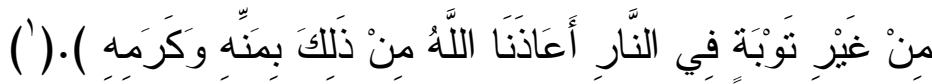

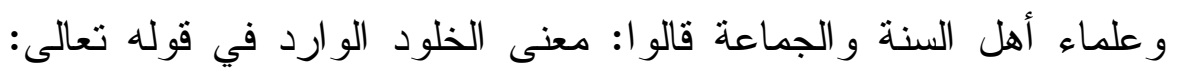

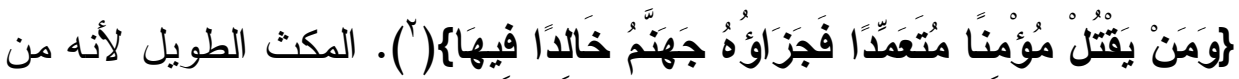
المعلوم أن الخلود خلودان: الأول: خلود مؤبد لا نهاية له، وهذا خلود الكفرة.

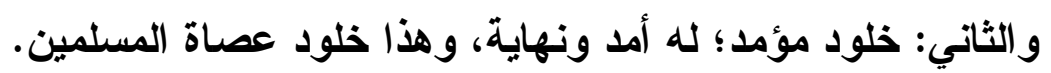
وقد يطول مكث بعض العصاة؛ لندة و عظم جريمته، كالقاتل و غيره؛ لكن مصيره إلى الجنّة ما دام مات على التوحيد و الإيمان.

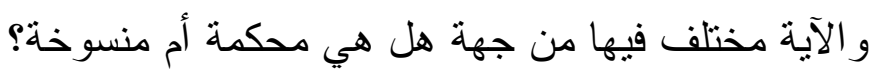

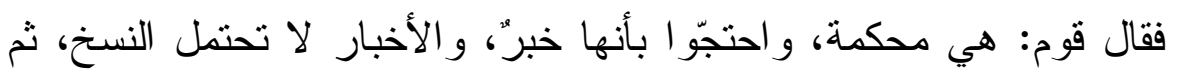
افترق هؤلاء فرقتين، إحداهما قالت: هي على ظاهرها، وقاتل المؤمن مخلد في (النار

و الفرقة الثانية قالت: هي عامة قد دخلها التخصيص بدليل أنه لو قتلك كافر، ثم أسلم الكافر، انهدرت عنه العقوبة في الدنيا و الآخرة، فإذا ثبت كونها من العامّ المخصّص، فأي دليل صلح للتخصيص وجب العمل به، ومن أسباب التخصيص أن يكون قاتَّه مُستحلاً، فيستحق الخلود لاستحلاله.

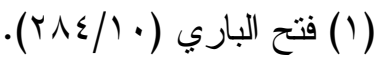

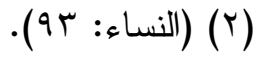


وقال قومُ: هي مخصوصة في حقّ من لم يَتب، و استدلو ابقوله تعالى في

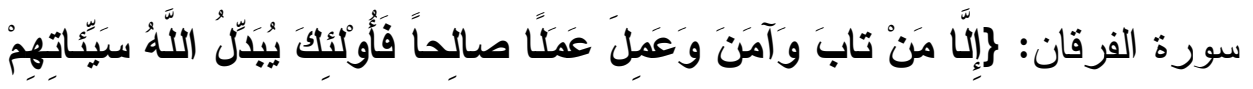

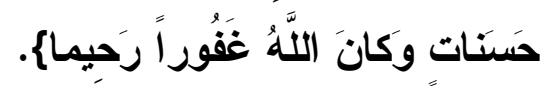

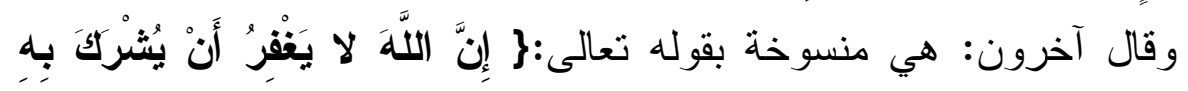

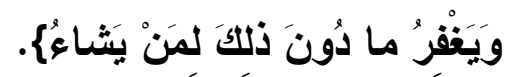

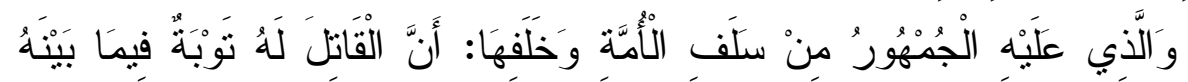

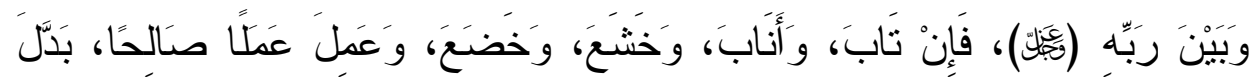

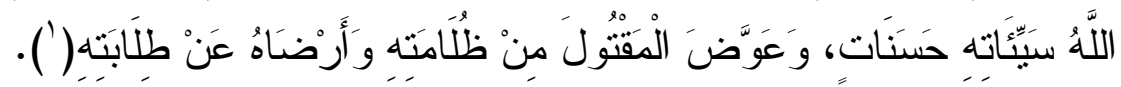




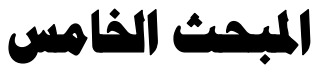 \\ بمضى هماذع إنفاذ وعيد الآله على عماة الاسلميسن:}

دلّت النصوص الثابتة على أعمال صالحة من قام بها أو ببعضها منع الله عنه إنفاذ ما تو عده به، منها: ا - التوحيد والإخلاص الله تعالى:

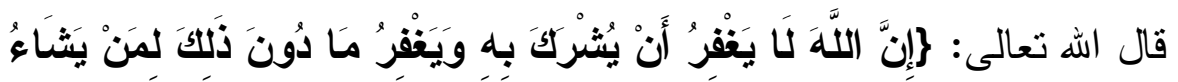

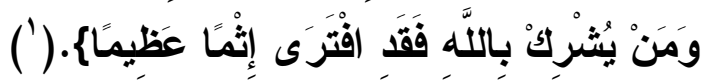

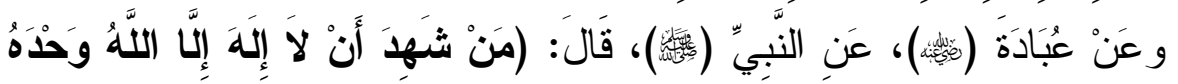

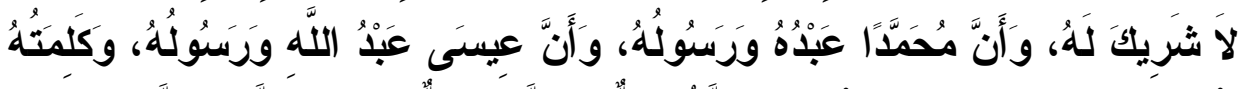

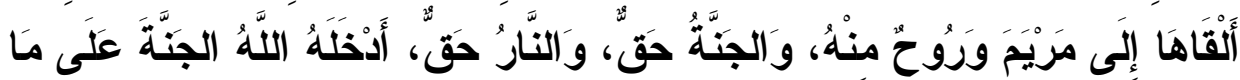

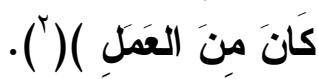

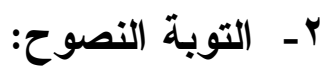

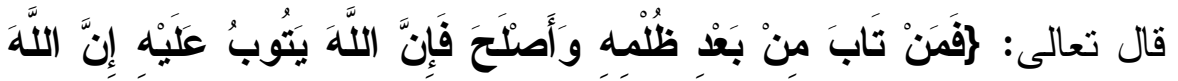

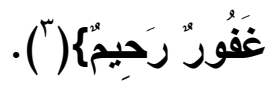

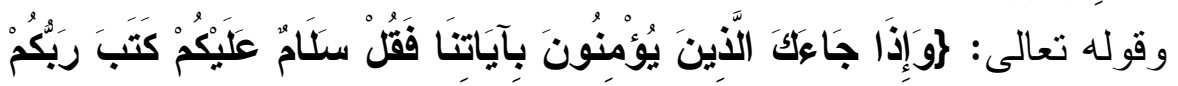

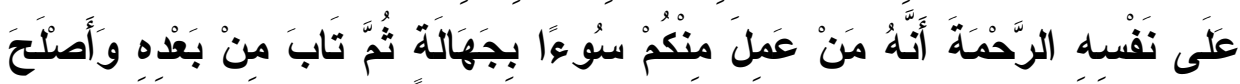

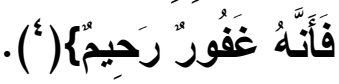

[النساء:(1)

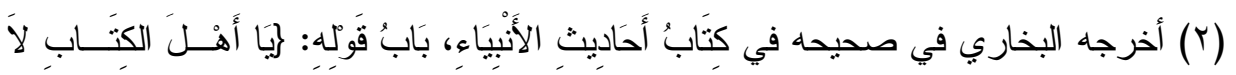

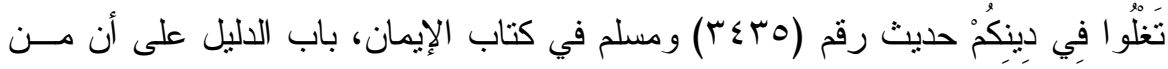

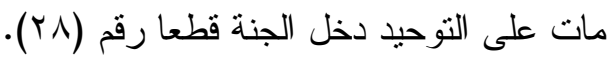




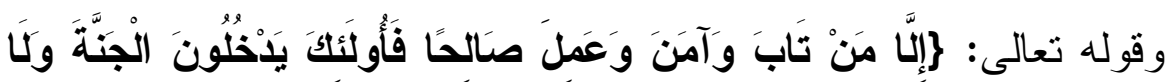

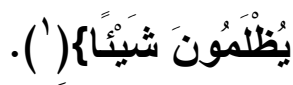

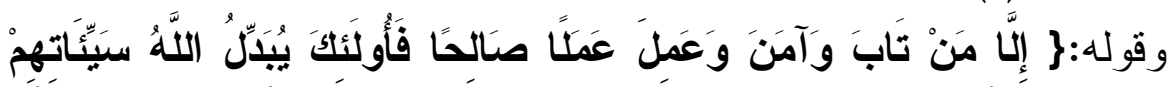

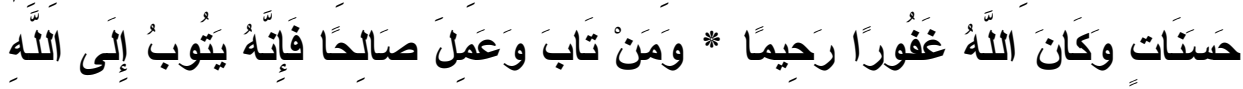

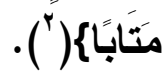

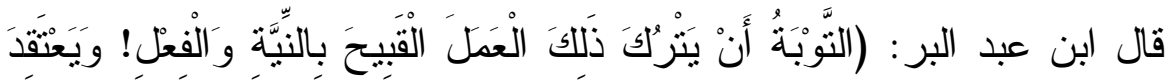

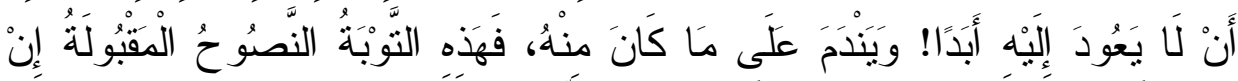

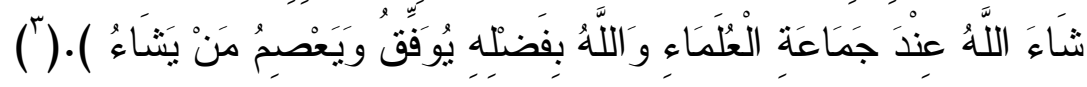
r- فعل الحسنات العظيمة مثل: الصلاة، و الصيام، والزكاة ونحوها:

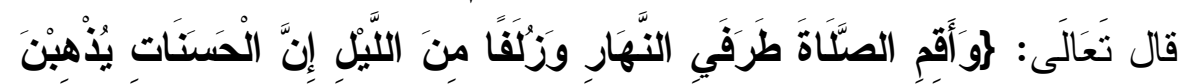

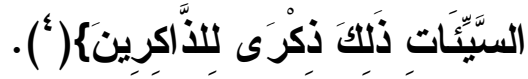

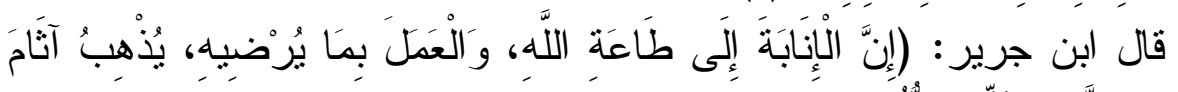

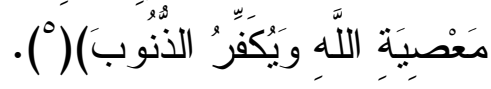
§ - الصبر و الاحتساب على المصائب و والابتلاءات:

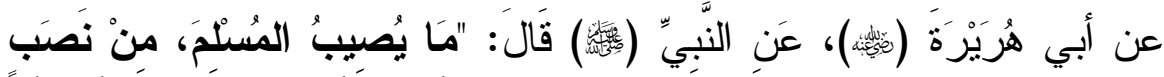

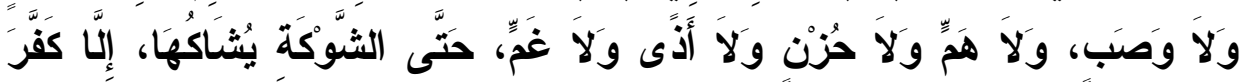

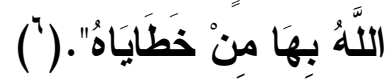

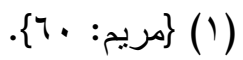

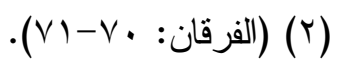

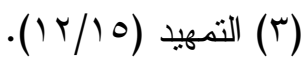

$$
\begin{aligned}
& \text {.\{11 }\{: \text { : } 1 \text { ( })
\end{aligned}
$$

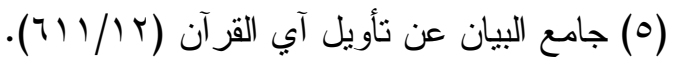

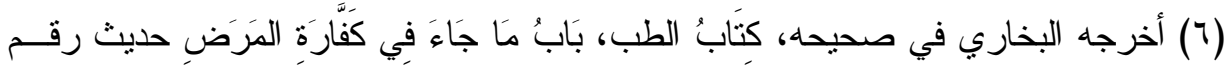




\section{الدكتور/ عبد الكريم بن إبراهيم آل غضية}

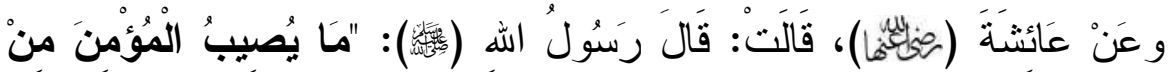

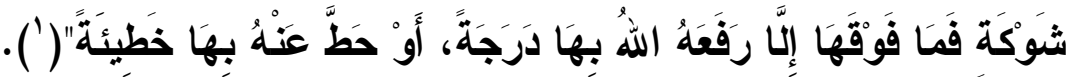
0- إقامة الحدود الشرعية في الانيا:

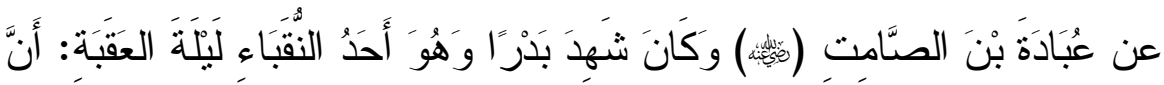

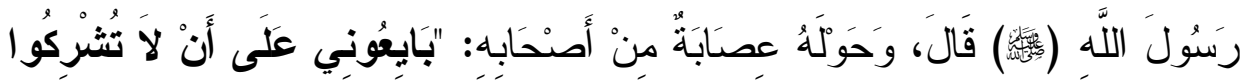

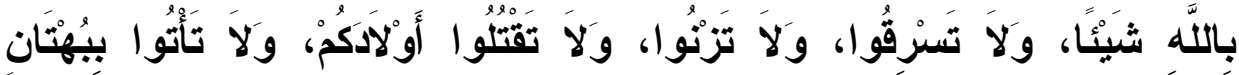

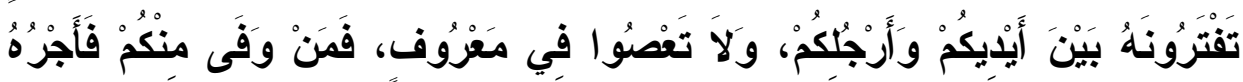

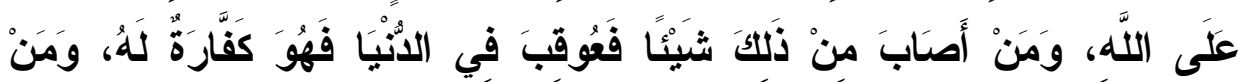

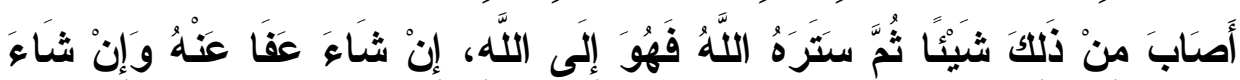

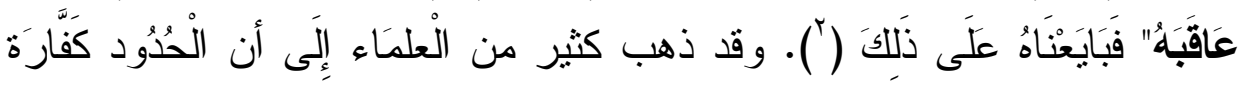
لهَذَا الحَديث.

و الحاصل - و الله أعلم - أن المذنب الموحد وإن كثرت ذنوبه وعظمت خطاياه؛ في مشيئة مو لاه، إن شاء عذبّه، و إن شاء عافاه، ونهايته الحنة و خلود

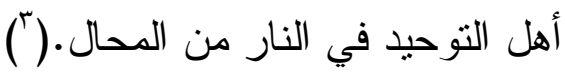

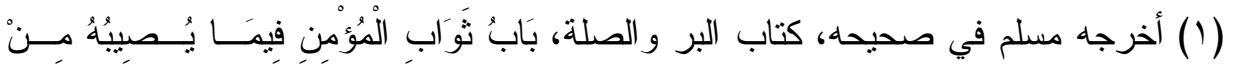

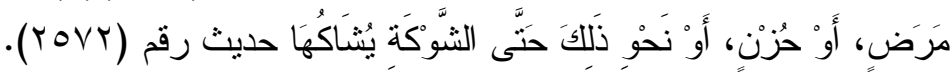

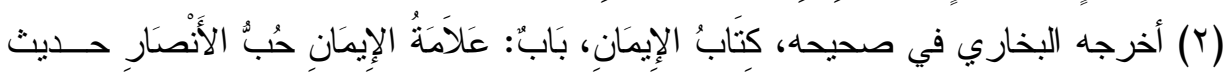

$$
\text { رقم (1) (1) - (1). }
$$

(r) أنظر كتاب: دلالة الأسماء الحسنى على التّزيه (YY/I). 


\section{(it)}

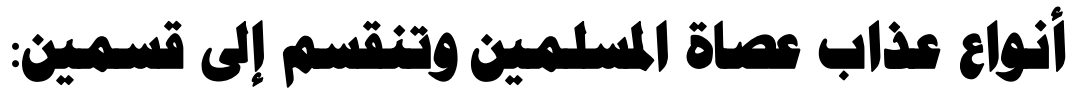

|اقمسم الأول: عذاب في الانيا وهو نوعان:

|لنوع |لأول: الابتلاءات العامة والخاصة !!

النوع الثانه: العقوبات الشرعية من حدود وتعزيرات

ونحوها.

القسبع الثانه: العذاب بعد الممات وهو خمسة أصناف:

\section{|لصن:مع |لأول: عذاب القبر !!}

الصنمع الثانه: العذاب بعد البعث حتى يقضى بين

$$
\text { العباد }
$$

الصنْع الثالث: العذاب -أثناء المرور على الصراط في جهنم الصنمع الرابع: العذاب في جهنم. العذابع الخامسر: بعد مجاوزة الصراط وقبل دخول الجنة(القتطرة) 
الدكتور/ عبد الكريم بن إبراهيم آل غضية

- Yr. 


\section{انواع عذاب عصاة المسلمين وينقسم إلمه قسمين:}

القسم الأول: عذاب في الانيا وهو نوعان: المان

النوع الأول: الابتلاءات العامة و والخاصة، مثَّل:

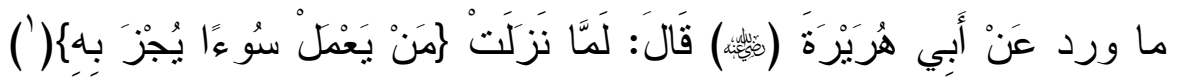

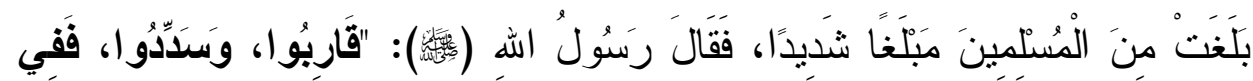

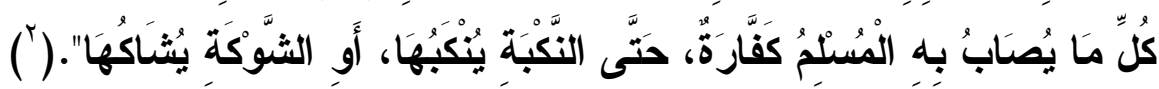

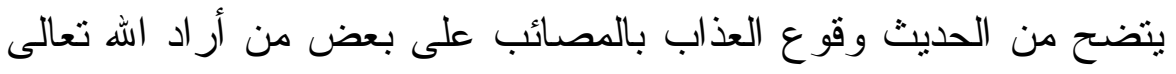

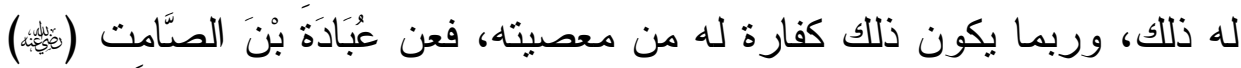

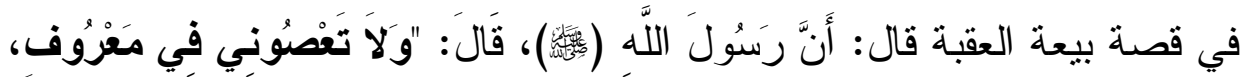

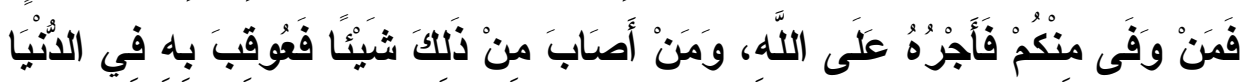

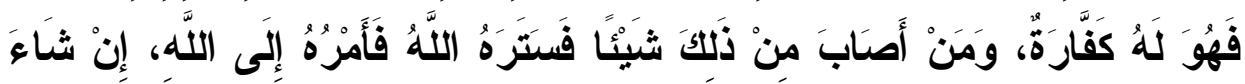

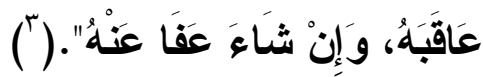
وقد ذكرت أدلة تكفير الابتلاءات للانوب في الفقرة الرابعة من المبحث

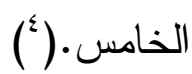

النوع الثاني: العقوبات الثرعية: (الحدود و التعزيز ات ونحوها).

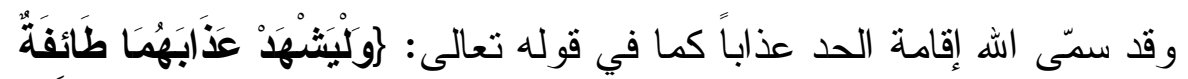

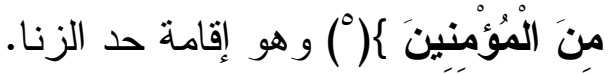

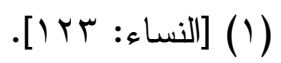

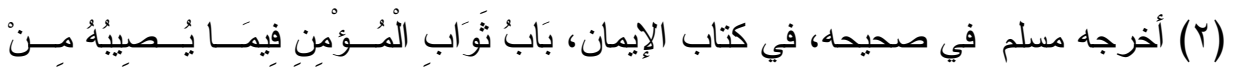

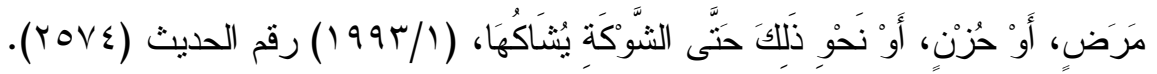

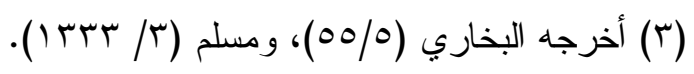

$\{r:$ : 


\section{الدكتور/ عبد الكريم بن إبراهيم آل غضية}

ويُطلق اسم العذاب: على العقوبة ولو للتأديب، كما في توعّد سليمان (الئلنّة)

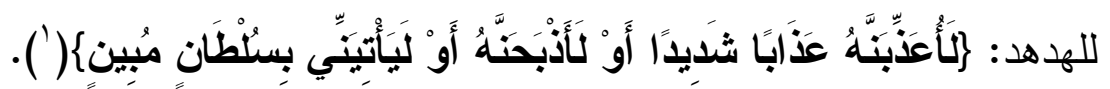
وقد ذكرت أدلة تكفير العقوبات الثرعية للذنوب في الفقرة الخامسة من

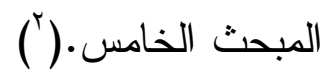

القسم الثاني: العذاب بعد الممات وهو خمسة أصناف: الصنف الأول: عذاب القبر

الصنف الثهاني: العذاب بعد البعث حتى يقضى بين العباد الصنف الثالث: العذاب - أثناء المرور على الصراط - في جهنم الصنف الرابع: العذاب في جهم بعد السقوط من على الصراط حتى شفاعة الشافعين الصنف الخامس: بعد مجاوزة الصر اط وقبل دخول الجنة(في القنطرة) 


\section{الصنفه الاول: عذ|ب| القبر:}

لقد تظاهرت نصوص الكتاب و السنة على إثبات فتنة القبر، وعذابه، ونعيمه، وأجمع على ذلك سلف الأمة من الصحابة و التابعين ومن بعدهم من أهل السنة و الجماعة، وما أنكره إلا من خالفهم من أهل البدع ولعه ولأهو اء.

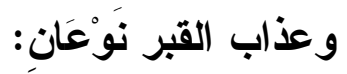

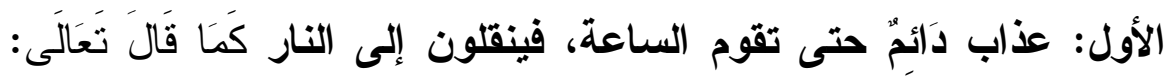

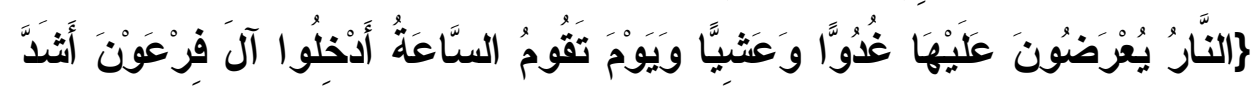

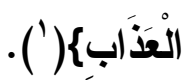

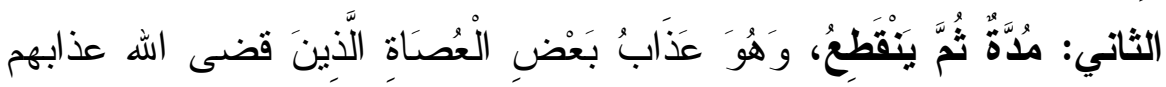

$$
\text { ليطهر هم به من عذاب النار . }
$$

وسأكتفي بذكر بعض الأدلة التي فيها ذكر لعذاب عصاة المسلمين وهي على نو عين:

النوع الأول: ضمة القبر التي لا ينجو منها أحد كان كبيراً أو صغيراً،(")

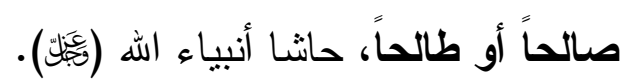

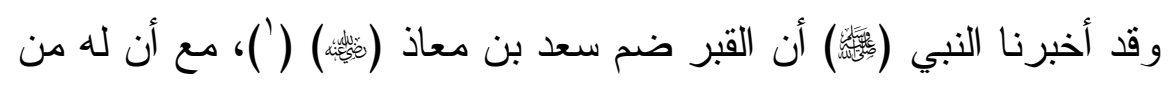

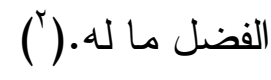

[غَافرِ : 7 [ 7 (1)

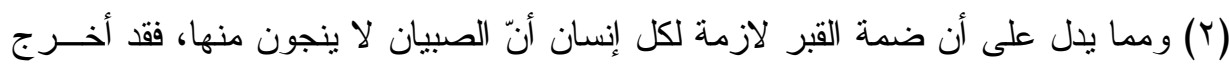

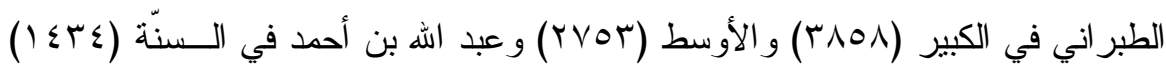

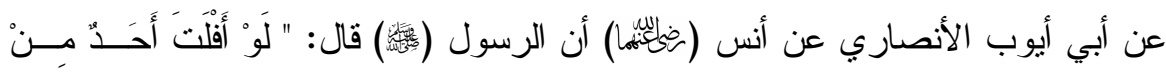

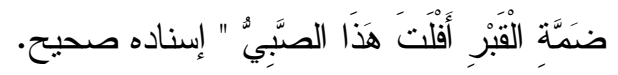




\section{الدكتور/ عبد الكريم بن إبراهيم آل غضية}

النوع الثاني: عذاب من أراد الله عذابه من المسلمين لينقيه، ويسلمه من

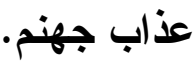

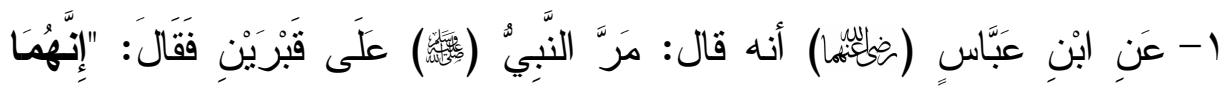

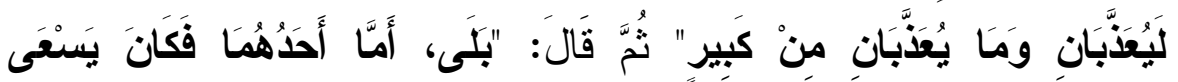

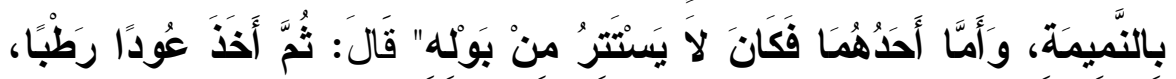

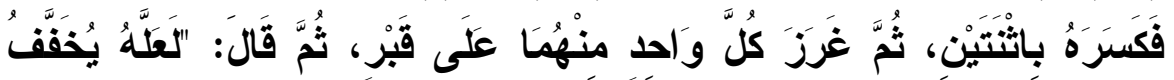

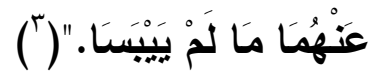

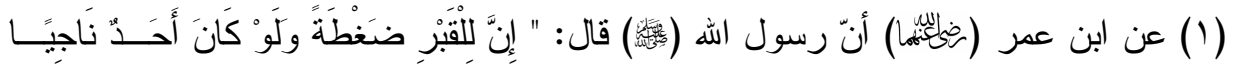

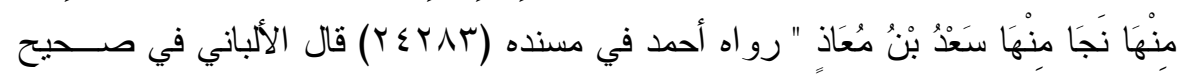
الجامع (T/YT/Y) : إسناده صحيح.

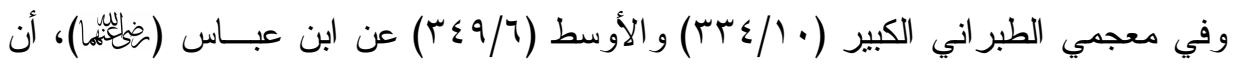

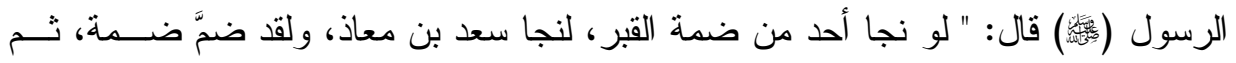

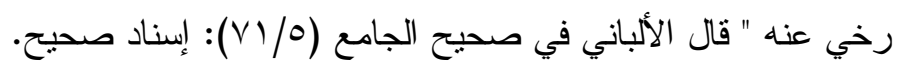

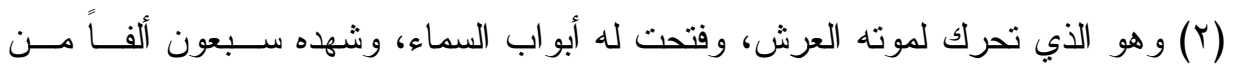

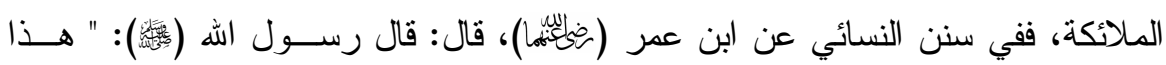

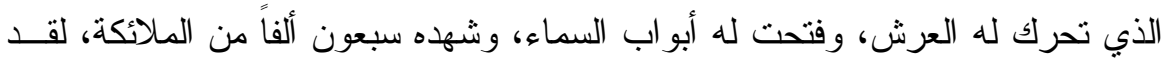

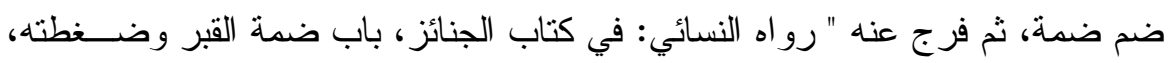

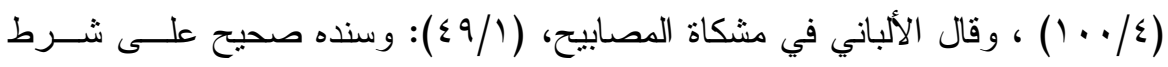

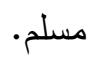

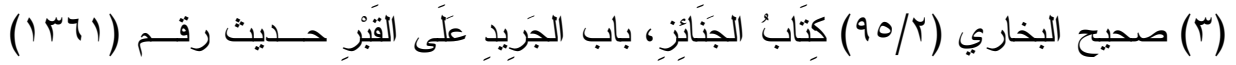

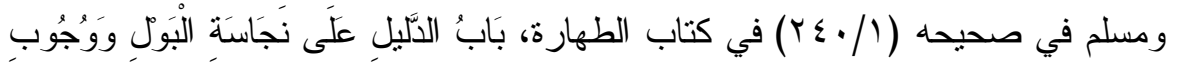

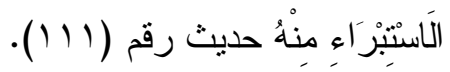


ففي هذا الحديث - على الأرجح - دليل صريح على أنّ المُعذبّين كَانَاً

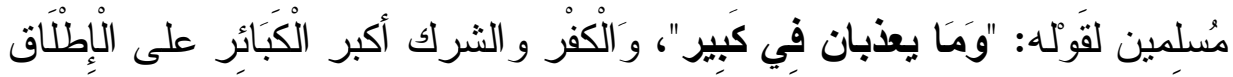
ولم بذكر هما.

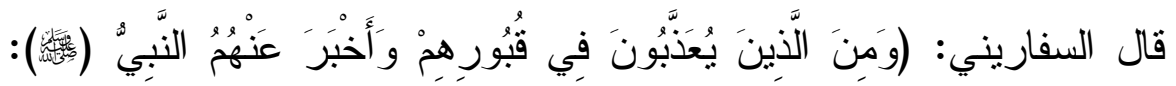

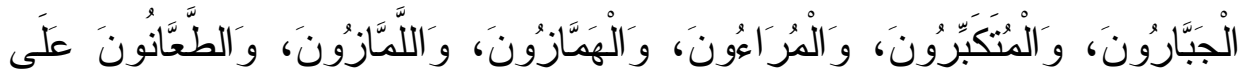

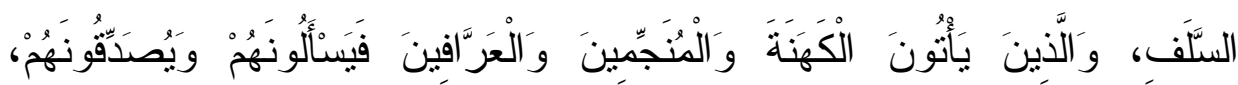

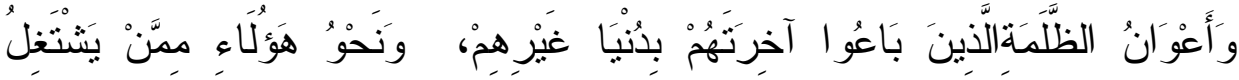

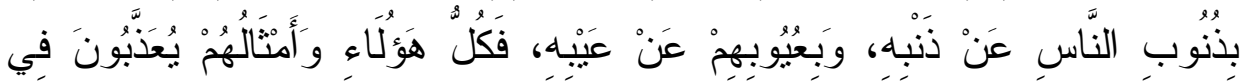

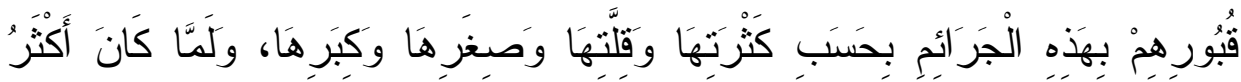

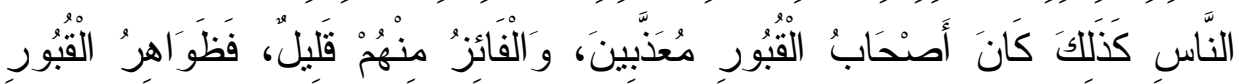

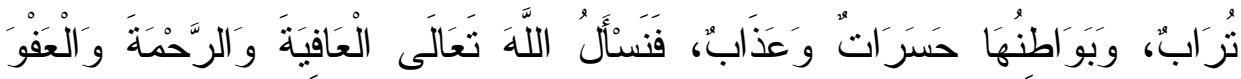

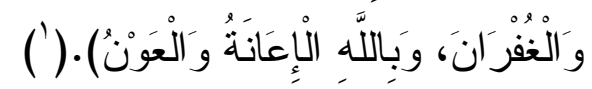

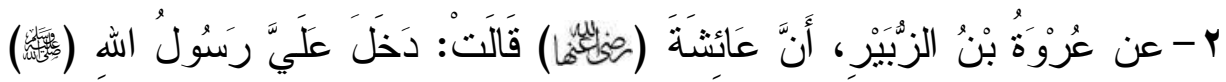

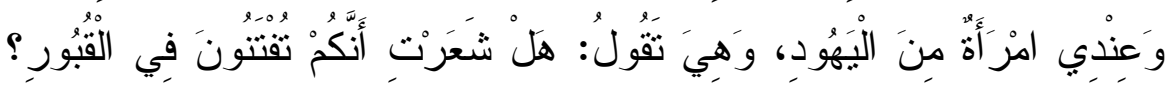

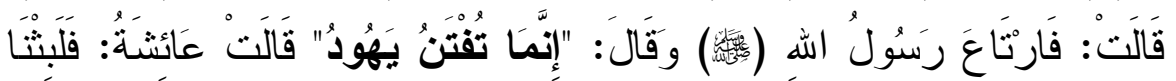

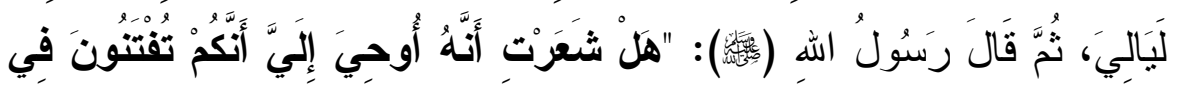

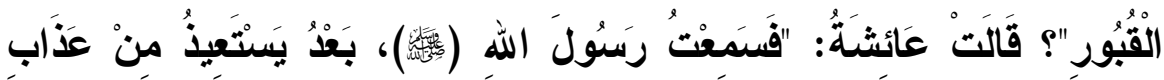

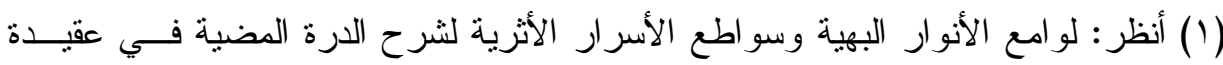

$$
\text { الفرقة المرضية (r/ (19/r). }
$$

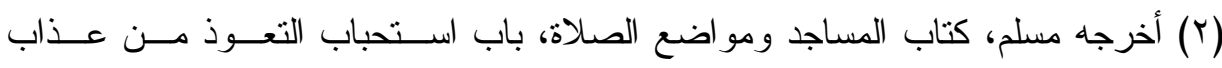

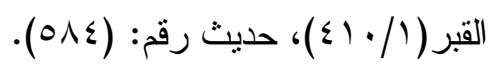




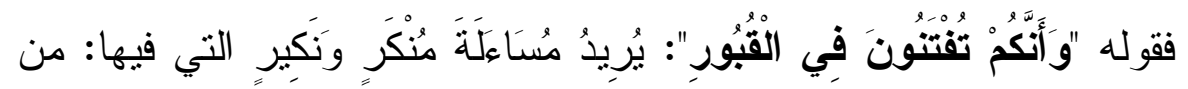

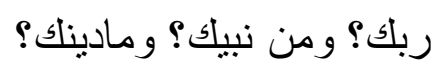

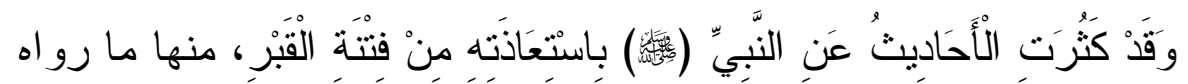

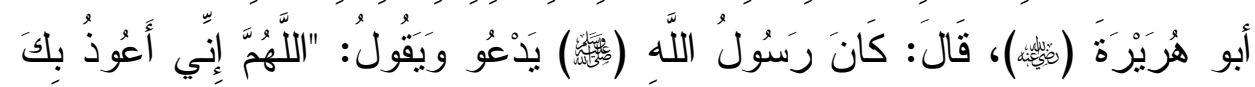

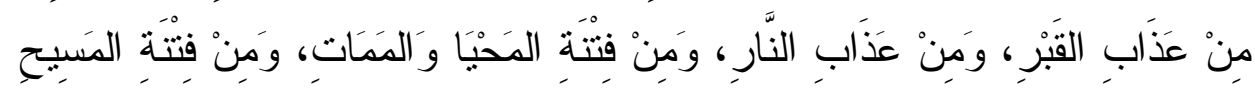

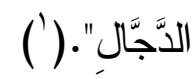
قالَ ابن بطال:" إن عذاب القبر حق على ما ذهب إليه أهل الستُّةَّ؛ ألا نزى

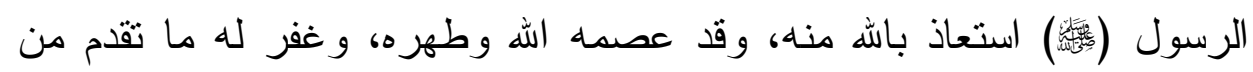

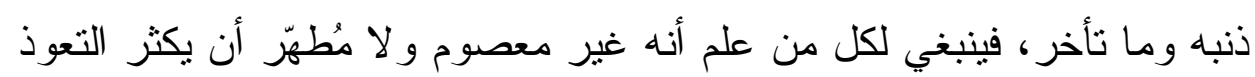

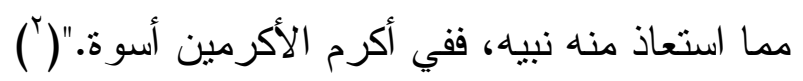
الصنفه الثانه: العذاب بعد البعث - وقبل دخول الجنة أو النار - حتى يقضى بين العباد: نصت كثير من الأدلة على وقوع عذاب بعد البعث؛ وقبل الدخول في النار، في عرصات القيامة، ومن ذللك ما ورد في عقوبة مانع الزكاة- من المسلمين-:

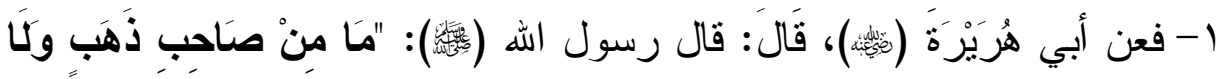

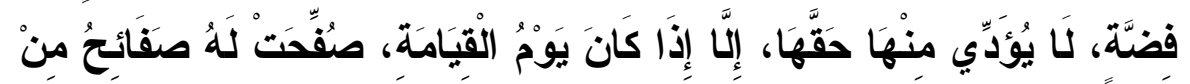

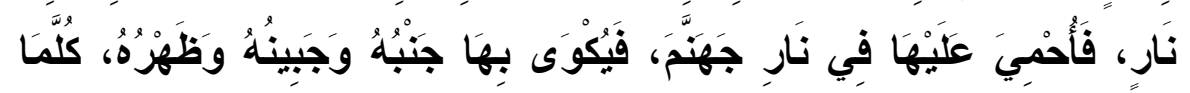

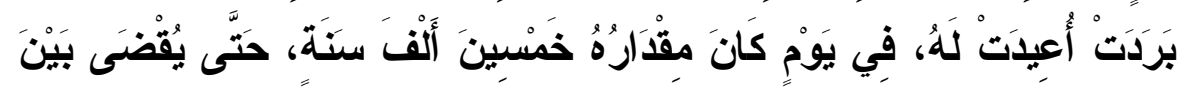

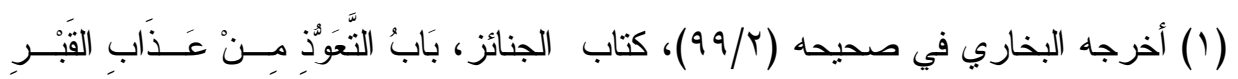

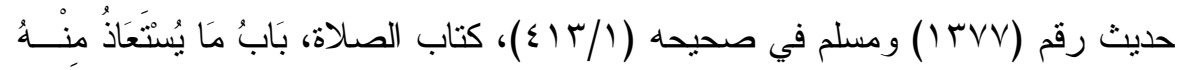

$$
\begin{aligned}
& \text { فِي الصََّّاة حديث رقم (IT) }
\end{aligned}
$$

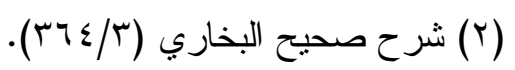




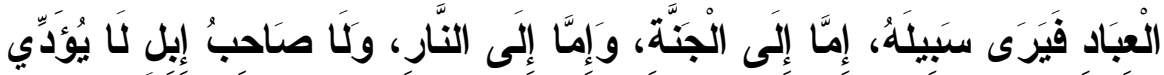

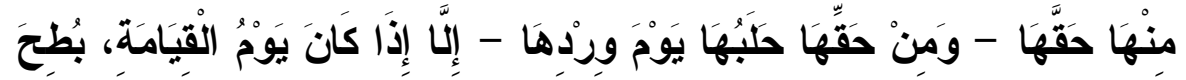

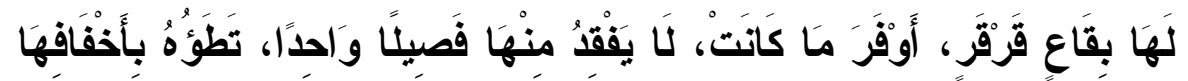

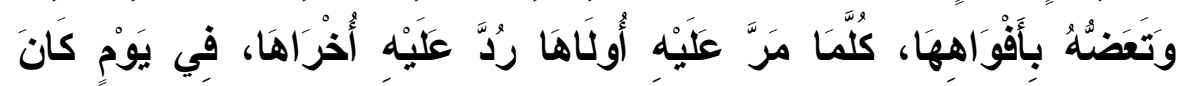

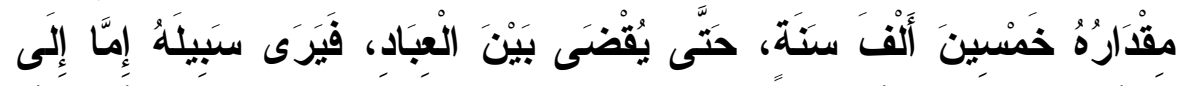

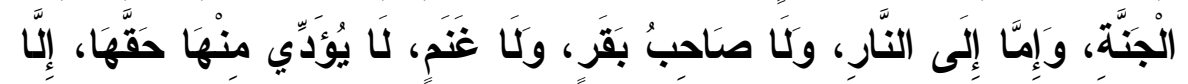

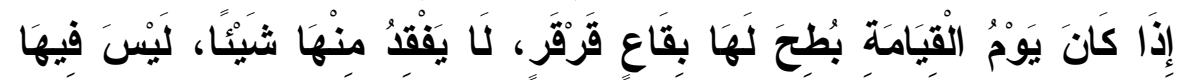

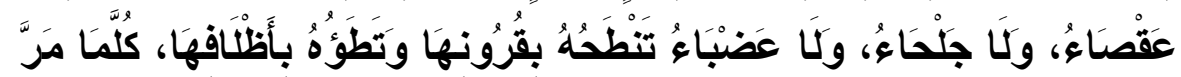

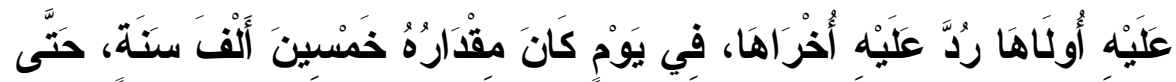

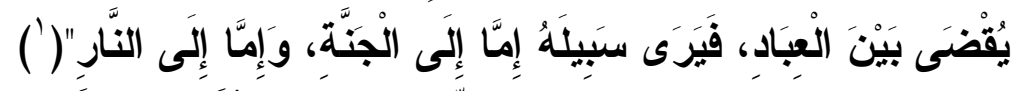

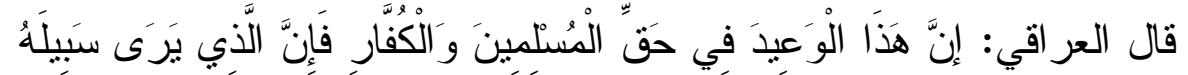

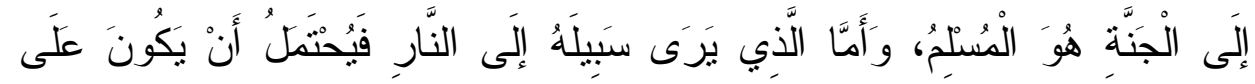

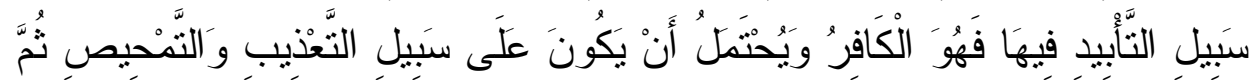

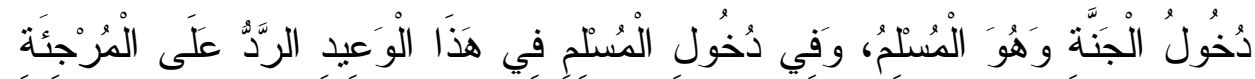

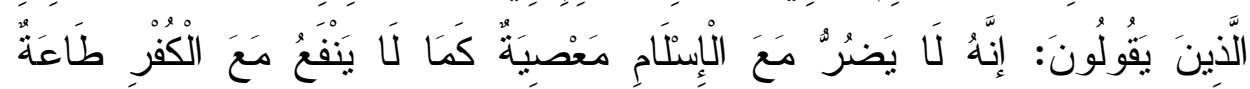

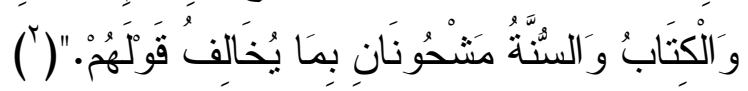

ץ-ومنل ما ورد في عذاب المتكبرين: "يحشر المتكبرون أمثال الذر يوم القيامة، في صور الرجال، يغشاهم الذل من كل مكان "(")

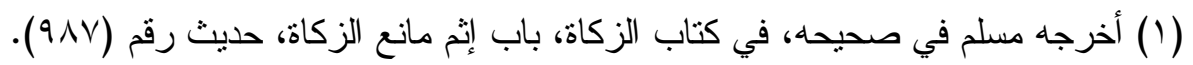

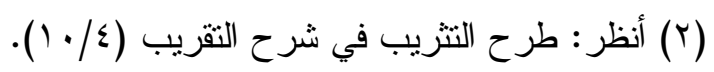

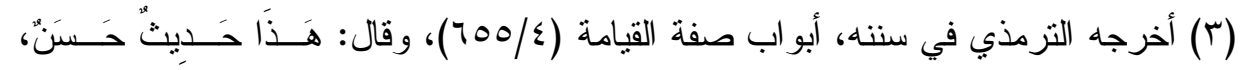

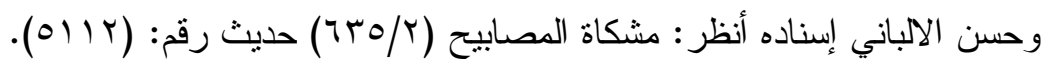


الصنفه الثالث: العذاب - أثناء المرور على الصراط - في جهنم، ولا يسقطون، لكن يتعرضون لخدوش وشقوق وتمزق للحومهم و أبشارهم:

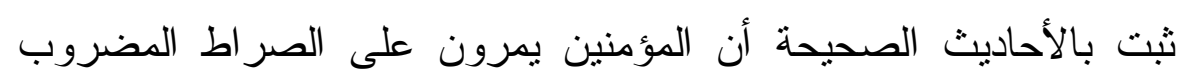

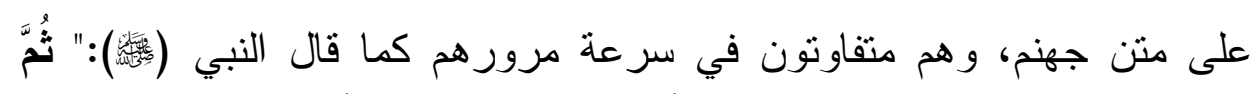

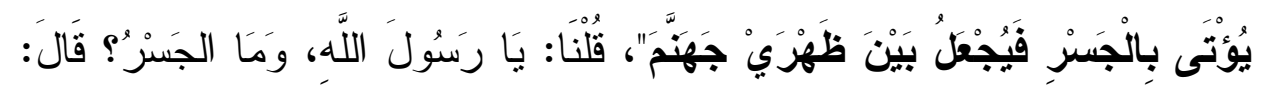

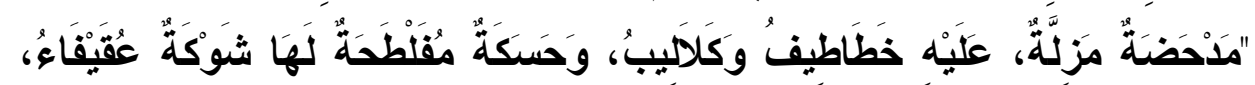

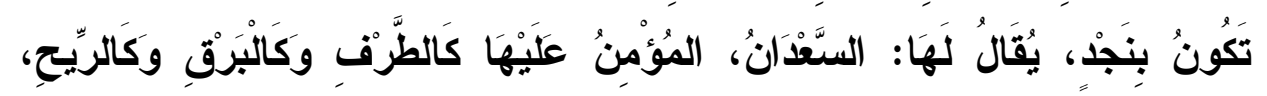

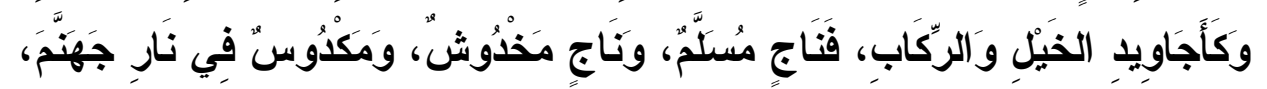

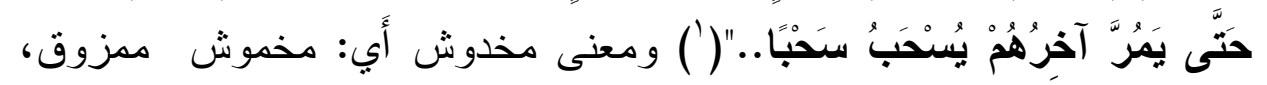

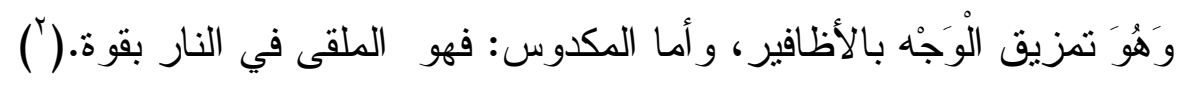

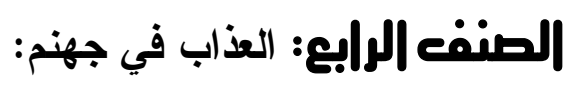
من سقط من المسلمين في النار - و العياذ باله - يخرجه الله بشفاعة

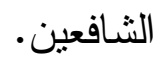
وذلك أن المؤمنين إذا تجاوزوا الصراط يققون ليتفقدوا إخوانهم، فيفقدون

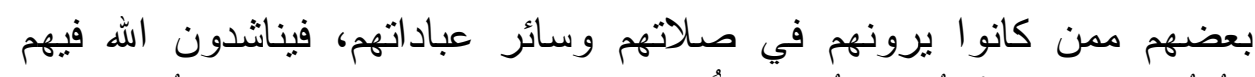

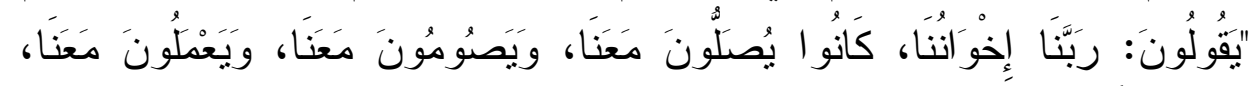

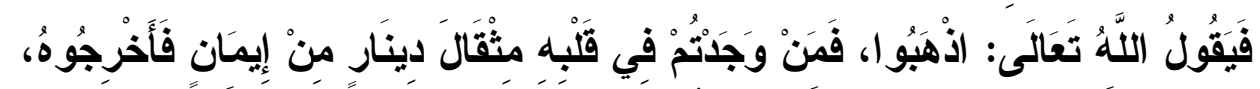

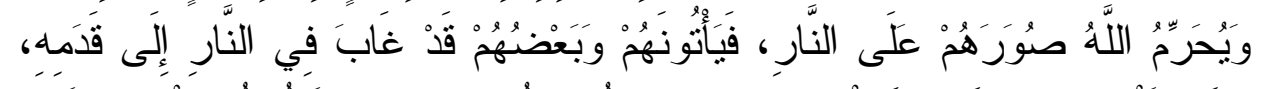

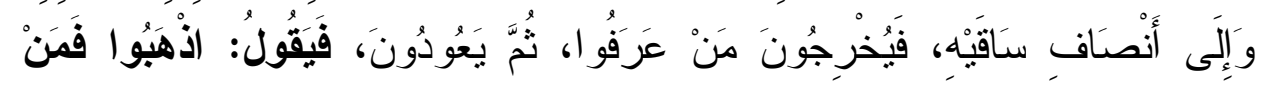

$$
\text { (1) (1) (أنظر نخريجه في الحديث الذي بعده. }
$$

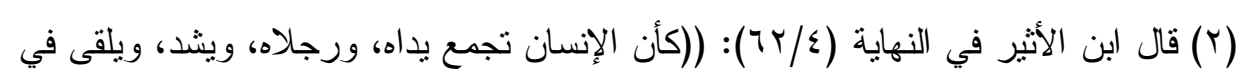

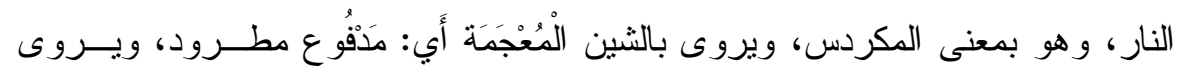

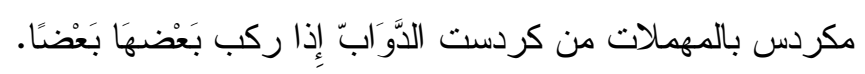




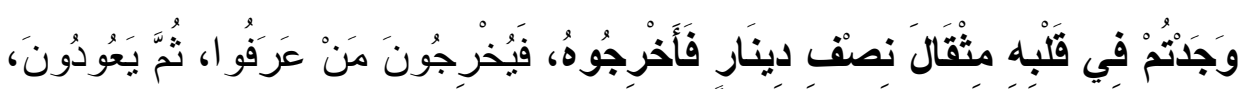

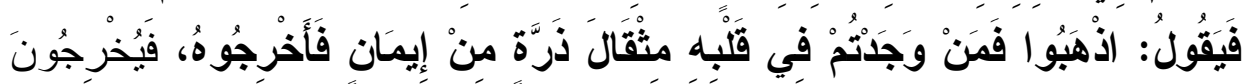

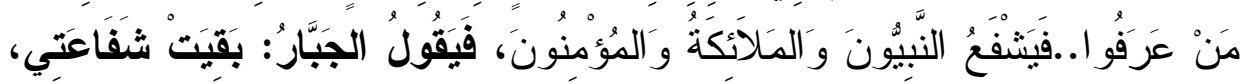

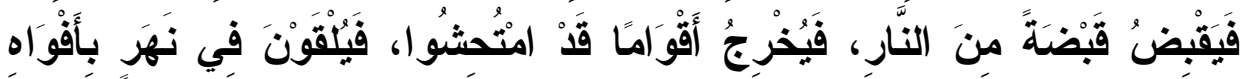

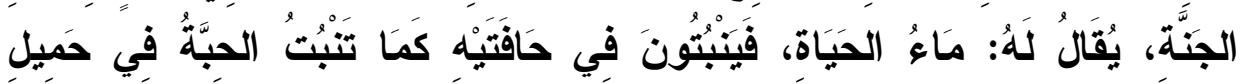

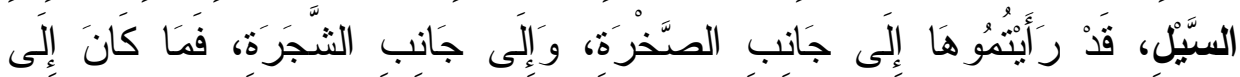

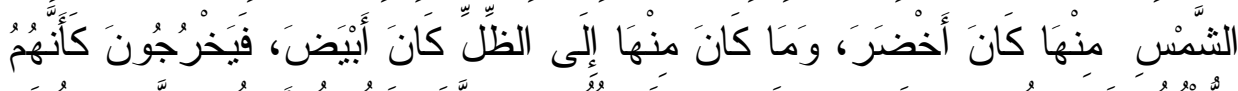

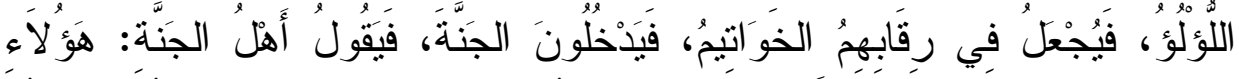

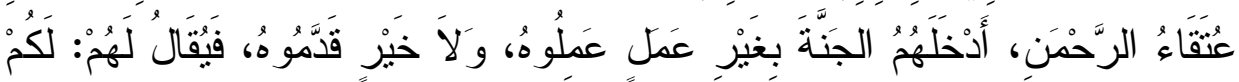

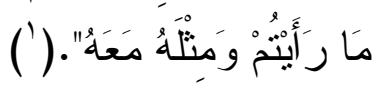

وبمجموع الأدلة الواردة في تعذيب عصاة المسلمين - الذي هذا منها نستفيد ما يلي: 1- عدم احتر اق أجسادهم بالكامل؛ إذ معنى الامتحاش: احتراق الجلد، وظهور

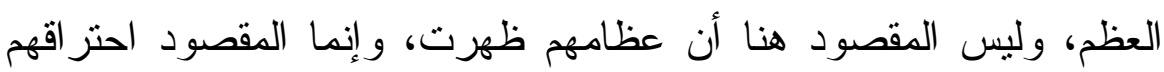

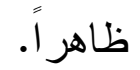

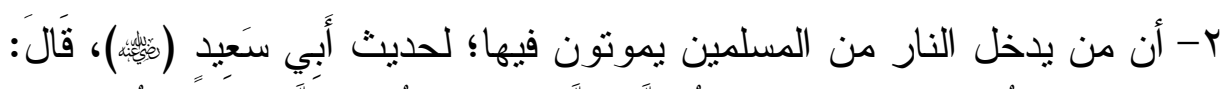

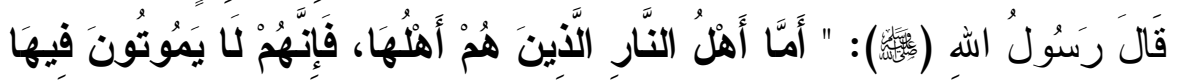

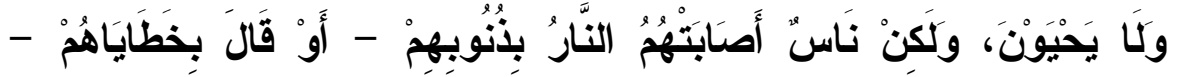

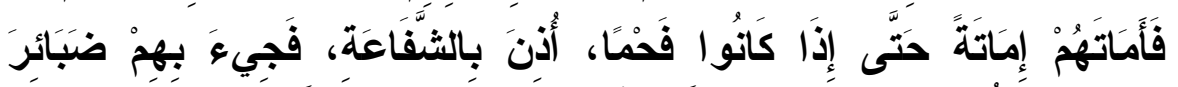

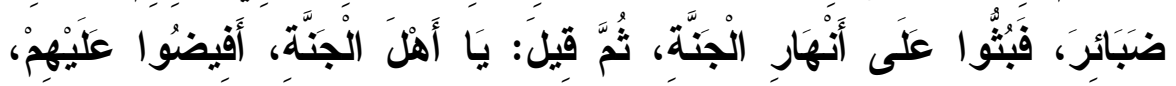

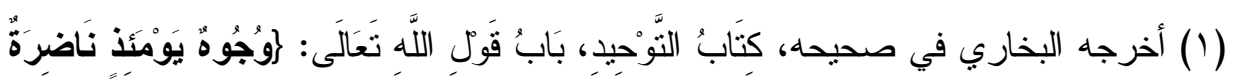

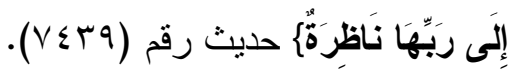




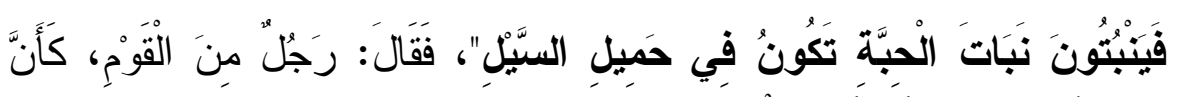

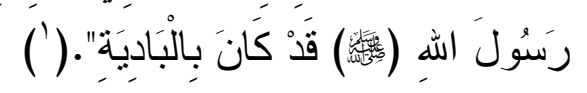

قال ابن رجب: (وظاهر الحديث يدل على أن هؤ لاء يموتون حقيقة، وتفارق

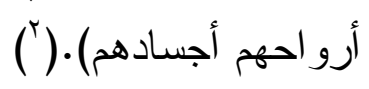

وحكى القاضي عياض: (فيه وجهان، أحدها: أنها إماتة حقيقية، و الثاني

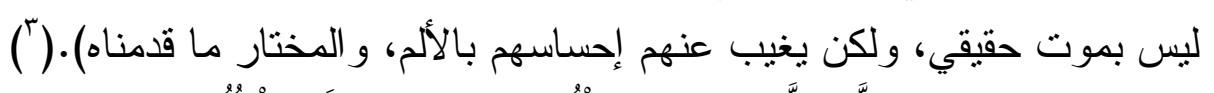

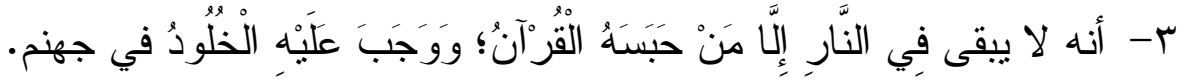

الصنفع الخامس: العذاب بعد مجاوزة الصراط وقبل دخول الجنة (في لأنئ

(القتطرة):

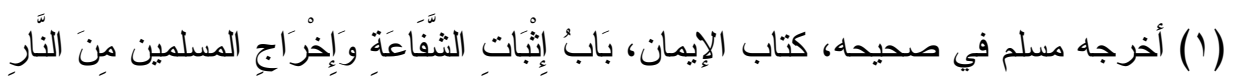

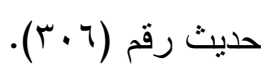

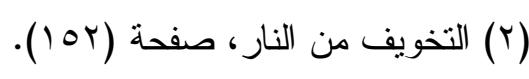

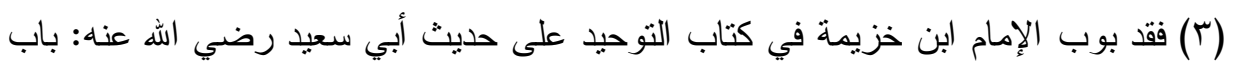

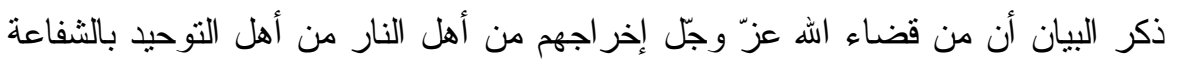

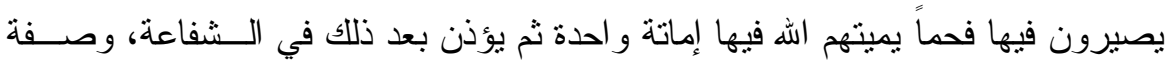

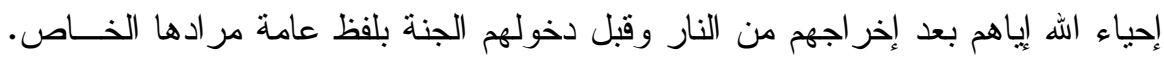

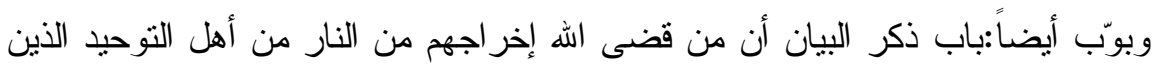

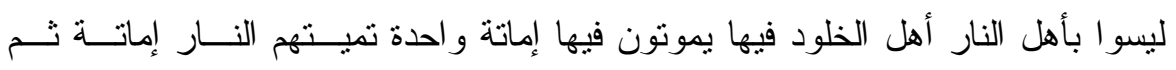

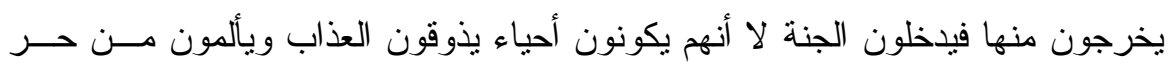

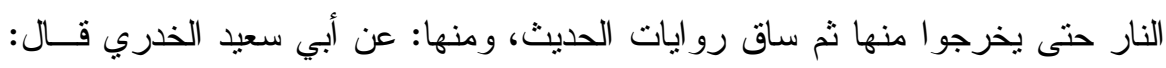

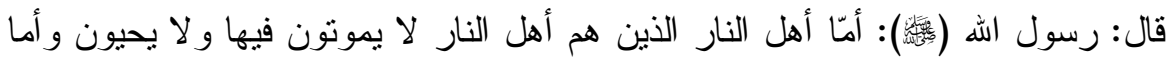

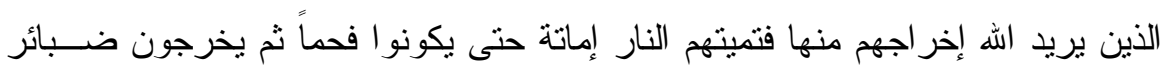
فيلقون على أنهار الجنة ويرش عليهم من مائها فينبنتون كما تتبت الحبة في حميل السيل. 
جاء في عدة أحاديث أن بعض المسلمين عندما يجنازون الصر اط يوقَفْنْ على قنطرة بين الجنة و النار، فينقون، ويهذبون، ويقتص لبعضهم من بعض،

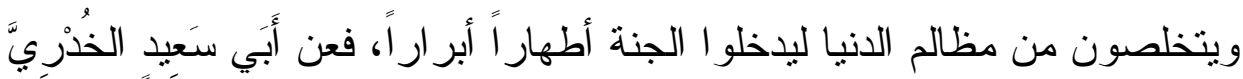

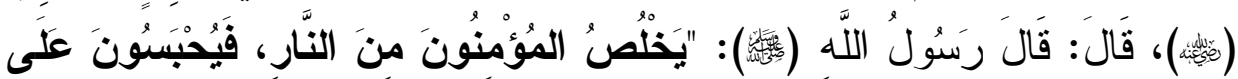

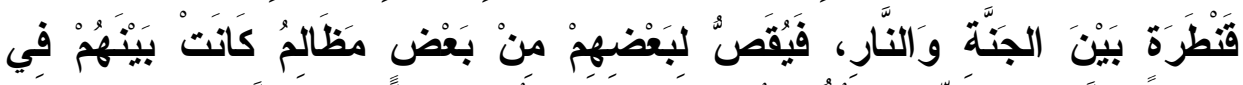

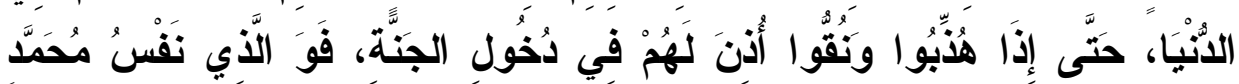

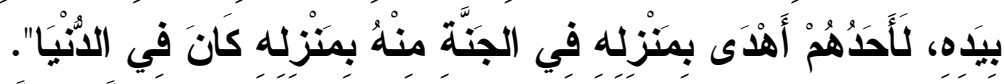

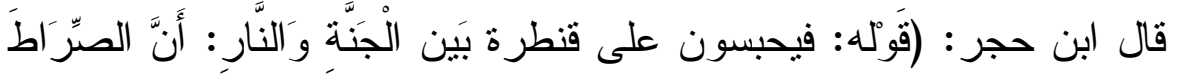

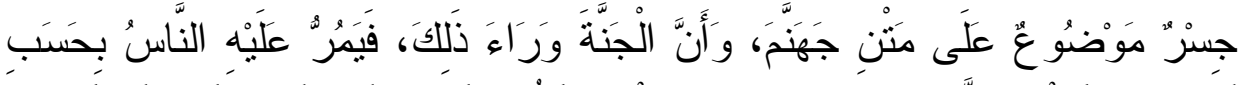

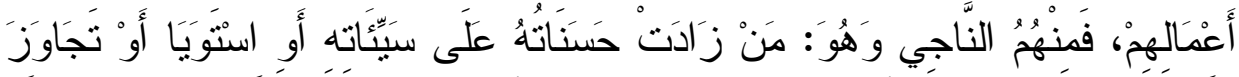

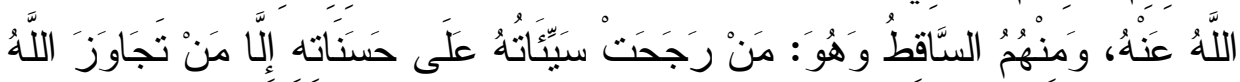

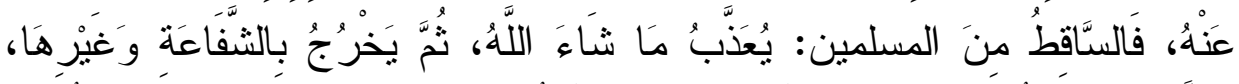

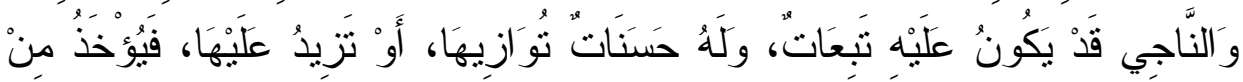

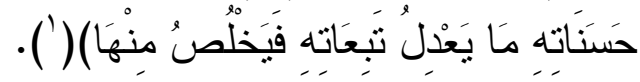
وبهذا نكون قد انتهينا من ذكر أنو اع العذاب الو اقعة على عصاة المسلمين

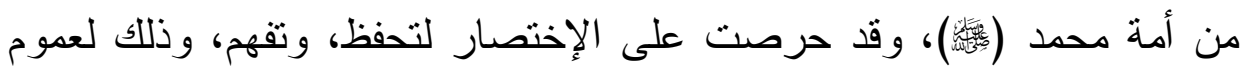

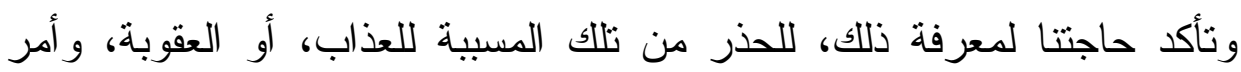

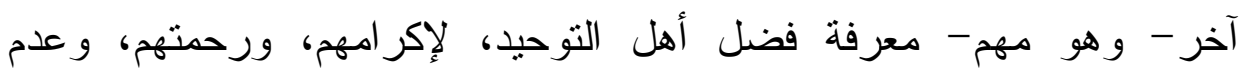
مساو اتهم بأهل الكفر و الطغيان، لأنهم من أهل الجنة التي أعدها الله لأوليائه،

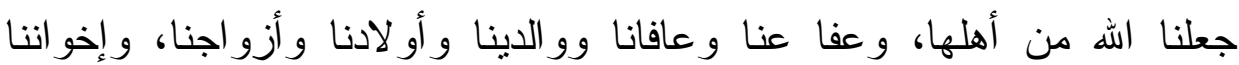
المسلمين عامة.

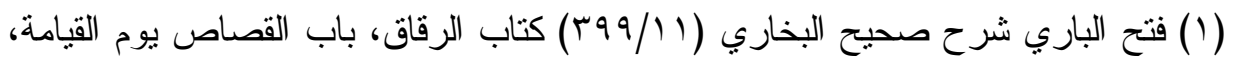

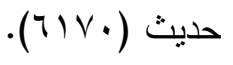




\section{الدكتورا عبد الكريم بن إبراهيم آل غضية}

\section{المراجـهـ}

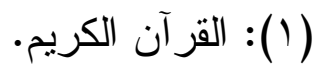

(r): الإحكام في أصول الأحكام، تأليف: سيف الدين أبي الحسن علي بن أبي

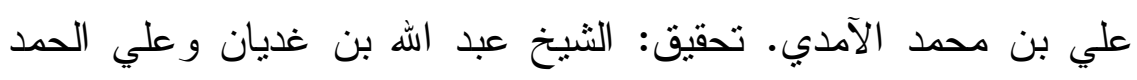

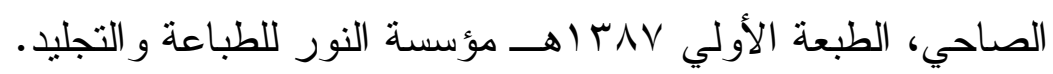

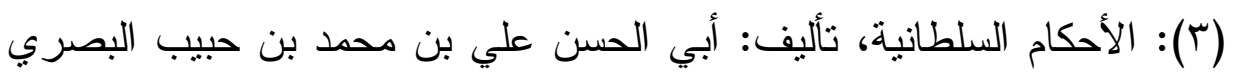

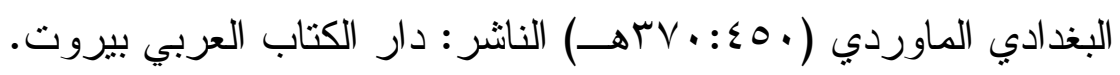

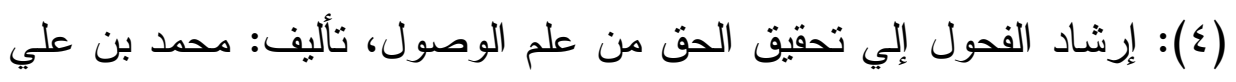

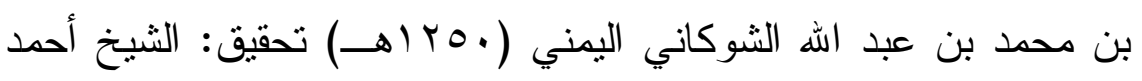
عزوعناية، دمثق: كفر بطنا، الناشر : دار الكتاب العربي، الطبعة الأولي الهي .

(0): أخبار القضاة، تأليف: أبوبكر محمد بن خلف بن حيان بن صدقة الضبي

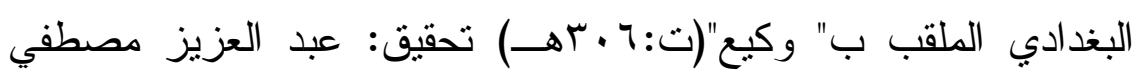

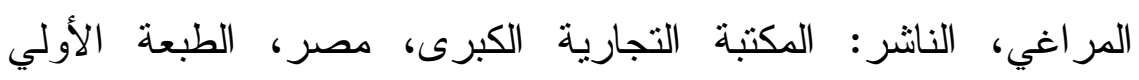
. 9 م 9 :

(†): الأمر بالمعروف والنهي عن المنكر، تأليف: تقي الدين أبو العباس أحمد

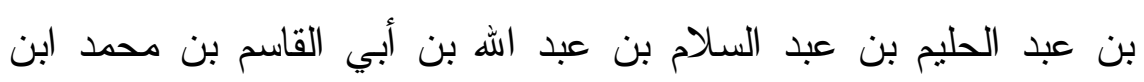

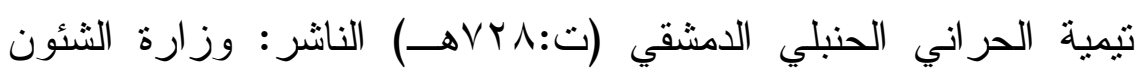

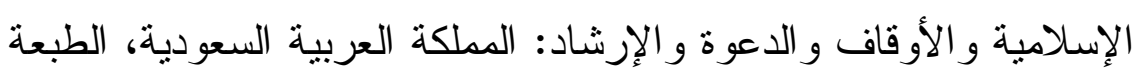

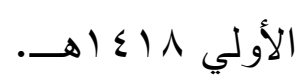




\section{عصاة السلمين وعدابهم في ضوي الكتاب والسنة}

(V): الآداب الثرعية و المنح المرعية، تأليف: محمد بن مفلح بن محمد بن مفرج أبو عبد الله شمس الدين المقدسي الرميني ثم الصالحي الحنبلي

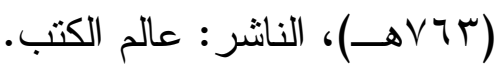

(^): إعلام الموقعين عن رب العالمين، تأليف: شمس الدين أبي عبد الله محمد

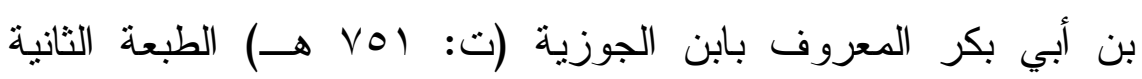

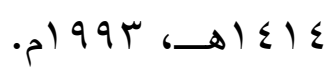

(9): أهمية الحسبة في النظام الإسلاهي، تأليف: عبد الرحمن بن حسن البيتي

$$
\text { تم استير اده من نسخة: الثاملة . . . 11. }
$$

(• (1): الأمر بالمعروف و النهي عن المنكر، تأليف: سليمان بن عبد الرحمن

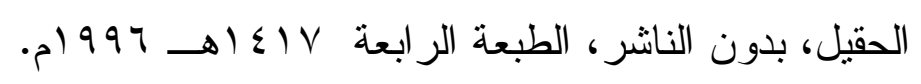

(1): الأدب المفرد، تأليف: للإمام الحافظ محمد بن اسماعيل البخاري

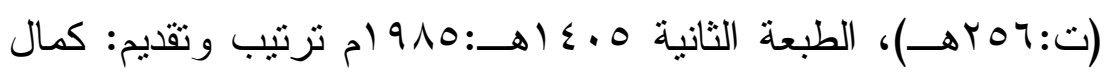

$$
\text { يوسف الحوت، نشر : عالم الكتب: بيروت. }
$$

(Y ( ) (البداية و النهاية، نأليف: أبي الفداء إسماعيل بن كثير البصري القرشي لئي

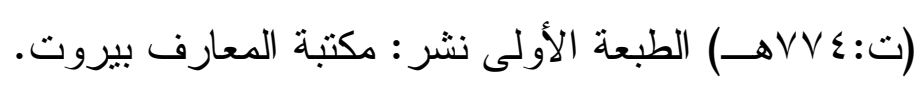

(r (1): البحر المحيط، تأليف: أبو حيان محمد بن يوسف بن علي بن يوسف بن بن

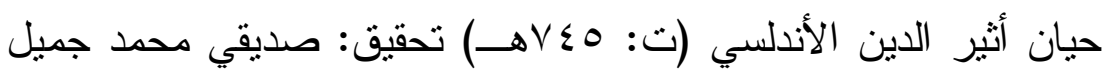

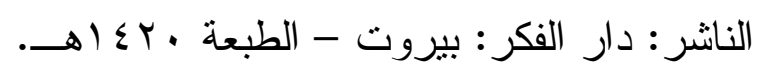

(ع ()): بحر العلوم، تأليف: أبو الليث نصر بن محمد بن إيراهيم السمرقندي

$$
\text { الفقيه الحنفي، تحقيق: د/محمود مطرجي، الناشر : دار الفكر : بيروت. }
$$




\section{الدكتورا عبد الكريم بن إبراهيم آل غضية}

(0 1): تهذيب اللغة، تأليف: محمد بن أحمد بن الأزهري الهروي، أبو منصور

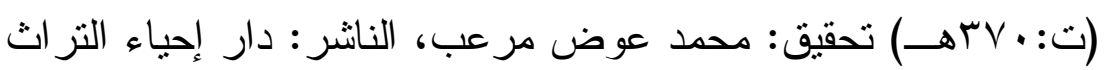

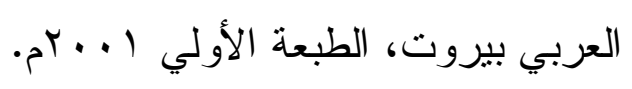

(7 (1): تاريخ بغداد، تأليف: أحمد بن علي بن ثابت الخطيب البغدادي

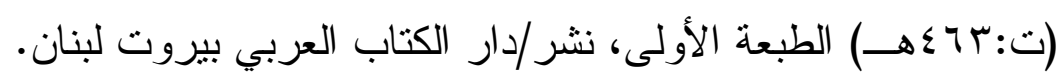

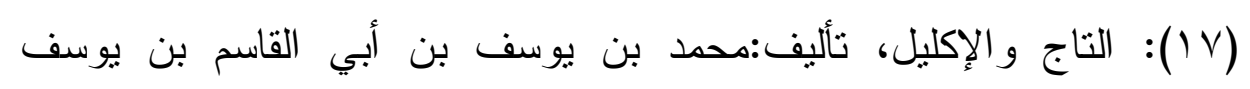

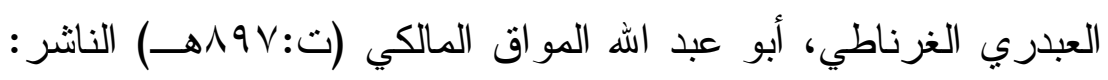

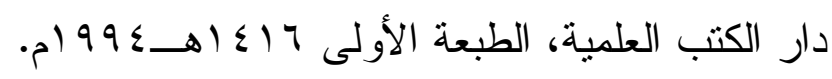
(1) (1): التاريخ الكبير ، تأليف:الإمام محمد بن إسماعيل البخاري (ت: بـهـهـ)، تحقيق: الثيخ عبد الرحمن المعلمي اليمني صورة عن الطبعة الأولى. (9 ()): تقسير القرآن العظيم، تأليف: أبي الفداء إسماعيل بن كثير البصري

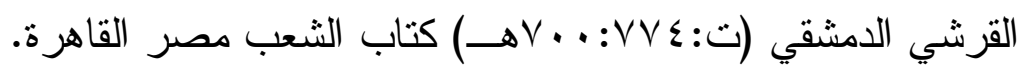

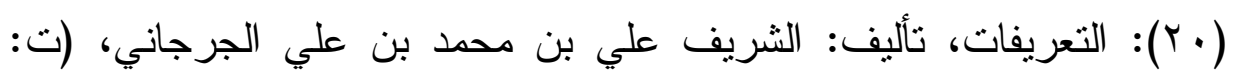

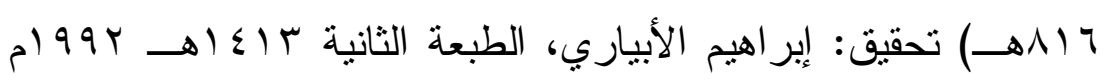

$$
\text { دار الكتاب العربي. }
$$

(Y): تقريب التهذيب، تأليف: أبو الفضل أحمد بن علي بن حجر العسقلاني،

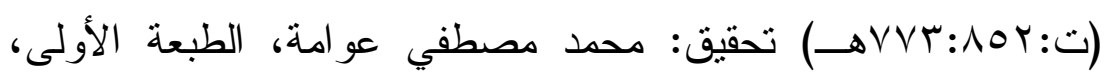

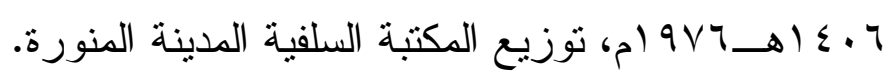

(Y) (Y): تيسير الكريم الرحمان في تفسير كلام المنان، تأليف: عبد الرحمن بن

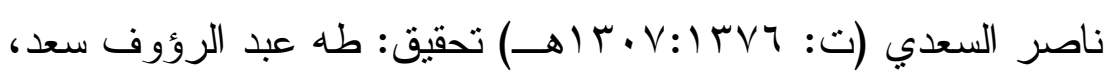

$$
\text { نشر مكتبة الأوس: المدينة المنورة: }
$$


(Y) ( أتفسير الكبير ، تأليف: أبو عبد الله محمد بن عمر بن الحسن بن الحسي التيمي الرازي الملق: بفخر الدين الرازي خطيب الري ل

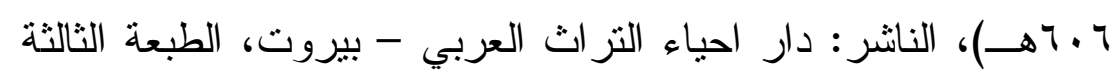
. $1 \leqslant r$. (Y0): التمهيد لما في الموطأ من المعاني والأسانيد، تأليف:الامام الحافظ أبي عمر يوسف بن عبد الله ابن محمد بن عبد البر النمري الاندلسي، (تحقيق: الأستاذ مصطفي بن أحمد العلوي و الأستاذ

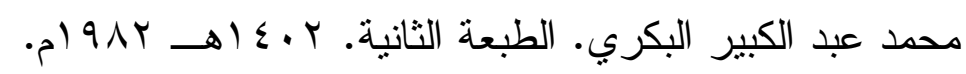
(YT): الجامع لأحكام القرآن، تأليف: عبد الله محمد بن أحمد الأنصاري

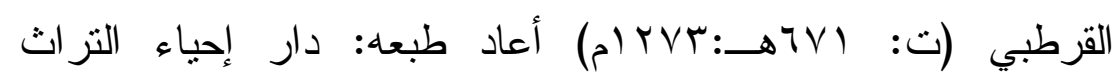
العربي: بيروت لبنان Vד 9 ام.

(YV)

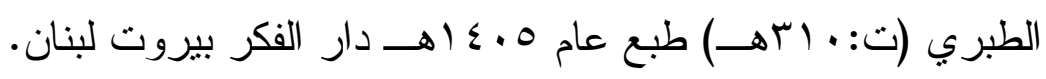

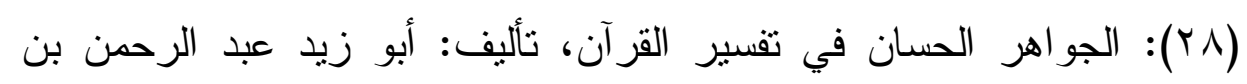

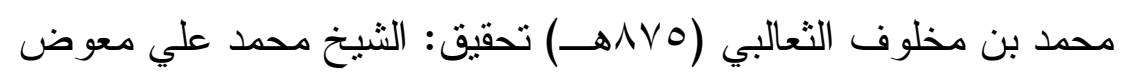
والثيخ عادل أحمد عبد الموجود، الناثر: دار إحياء التزاث العربي

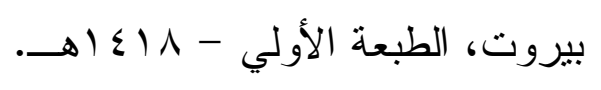
(Yq) الجامع الصحيح و هو سنن التزمذي، تأليف: أبو عيس بن سورة التزمذي (ت:YV9 مطبعة مصطفى البابي الحلبي و أو لاده القاهرة. 


\section{الدكتور/ عبد الكريم بن إبراهيم آل غضية}

(·) (ب) دلائل النبوة، تأليف: أبي بكر أحمد بن الحسين البيهقي (ت:

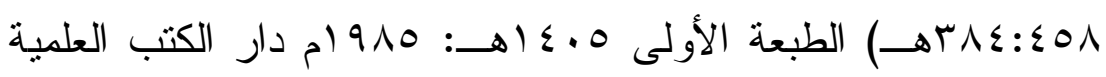

$$
\text { بيروت: لبنان. }
$$

(1): رسوم التحديث في علوم الحديث، تأليف: برهان الدين أبو إسحاق

إير اهيم بن عمر بن إير اهيم بن خليل الجعبري (ت:

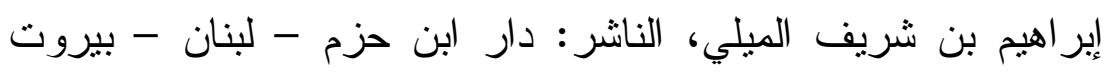

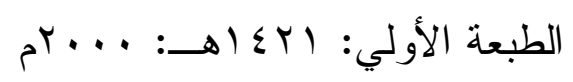

(ץr): رسالة الأدلة الكاشفة لأخطاء بعض الكتاب، لسماحة الثيخ/ عبد العزيز

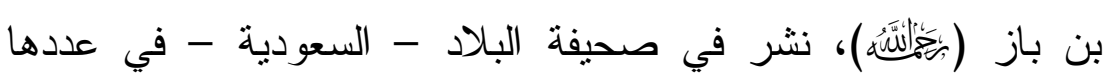

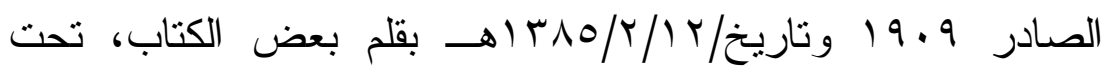

$$
\text { عنو ان: (احذروا الغلو). }
$$

(Tr): روح المعاني، تأليف: شهاب الدين محمود بن عبد الله الحسيني الألوسي

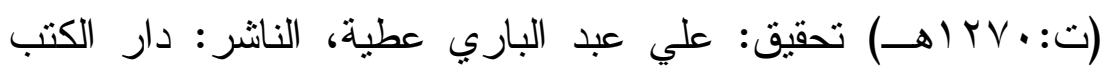

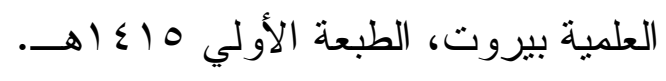

( (ץ): ز اد المسير في علم التفسير، تأليف:جمال الدين أبو الفرج عبد الرحمن بن علي بن محمد الجوزي (ت:V9هـــ تحقيق: عبد الرزاق المهدي

$$
\text { الناشر:دار الكتاب العربي: بيروت. }
$$

(0): سلسلة الأحاديث الضعيفة، نأليف: الثيخ ناصر الدين الألباني، الطبعة

$$
\text { الر ابعة ه9 § اهـــ المكتب الإسلامي بيروت: لبنان. }
$$

(דب): السياسة الثرعية في، تأليف: أحمد بن عبد الحليم بن تيمية الحراني

$$
\text { الناشر : دار المعرفة. }
$$




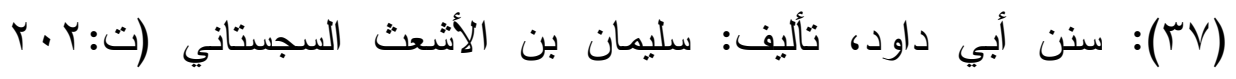
(اعتني به أبي عبيدة مشهور بن حسن آل سليمان، طبعه

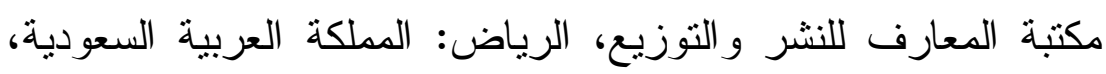
الطبعة الثانية.

(†^): سير أعلام النبلاء، تأليف: الإمام شمس الدين محمد بن أحمد بن عثمان

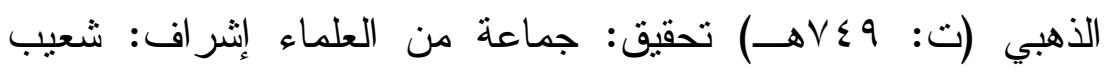
الأرنؤوط الطبعة الأولي 1 الـ الهـ، مؤسسة الرسالة. (ץ): شعب الإيمان، تأليف: أبو بكر أحمد بن الحسين البيهقي الناشر : دار

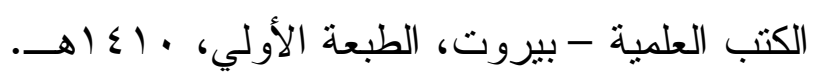
(•): شرح العقيدة الطحاوية، تأليف: علي بن علي بن محمد بن أبي العز الحنفي تحقيق: أحمد شاكر، طبعة مكنبة الرياض الحديثة، الرياض: المملكة العربية السعودية. (1): شرح للمسلم، تأليف: أبو زكريا محيي الدين يحي بن شرف النووي

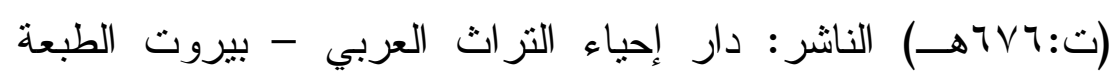

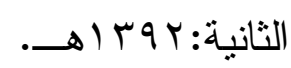

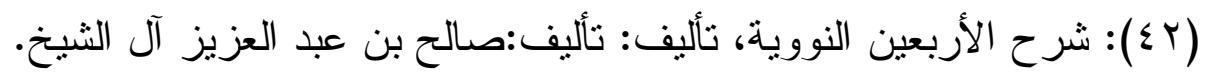

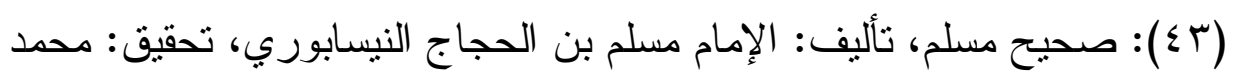
فؤاد عبد الباقي، طبعة دار إحياء الكتب العربية عيسي البابي الحلبي

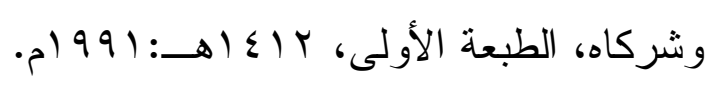

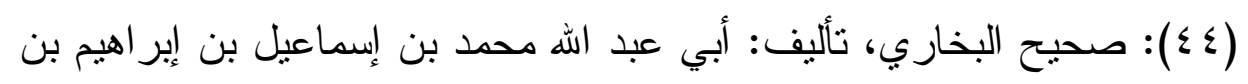

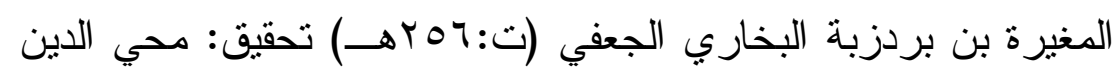




\section{الدكتور/ عبد الكريم بن إبراهيم آل غضيد}

الخطيب ترقيم محمد فؤاد عبد، طبعة المكتبة السلفية القاهرة - مصر

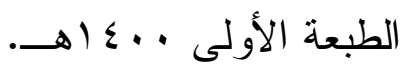

(؛): صحيح الجامع، تأليف: محمد ناصر الدين الألباني، الطبعة الثانية

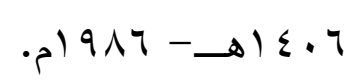

(T) (7): صحيح ابن ماجه، تأليف، الحافظ أبي عبد الله محمد بن يزيد القزويني، تحقيق وتعليق وترقيم: الأحاديث و الأبواب محمد فؤاد عبد الباقي، دار

$$
\text { احياء التراث العربي، بيروت - لبنان. }
$$

(\&V)

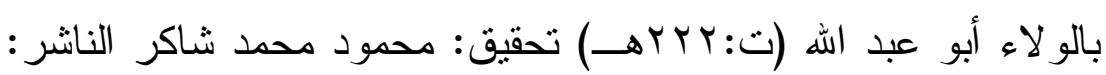
دار المدني.

(^^) (العدة في أصول الفقه، تأليف: القاضي أبو يعلي، محمد بن الحسين بن

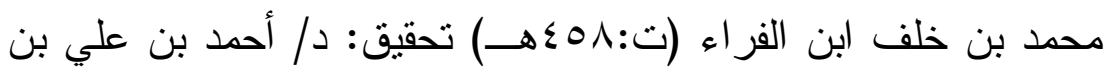
سير المباركي، الأستاذ المساعد المشارك في كلية الثريعة بالرياض جامعة الملك محمد بن سعود الإسلامية، بدون ناشر . الطبعة الثانية:

$$
\text { . ) } 99 \text {. } \rightarrow \leq 1 \text {. }
$$

(9)): عارضة الأحوذي بشرح صحيح الترمذي، تأليف: أبي بكر محمد بن عبد الله بن الربي (ت:بــهــ) نشر دار الوحي المحمدية - القاهرة. ( •(م): العزلة والانفر اد، تأليف: أبو بكر عبد الله بن محمد بن عبيد بن سفيان

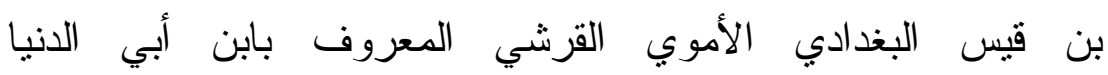

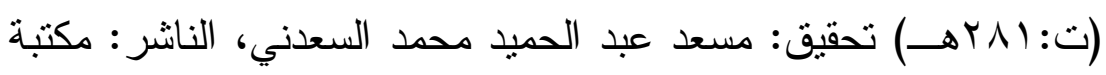

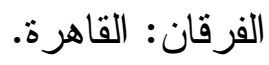


(10): العزلة، تأليف: أبو سليمان حمد بن محمد بن إبر اهيم بن الحطاب البستي

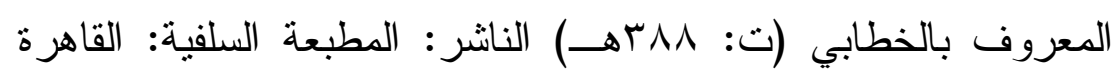

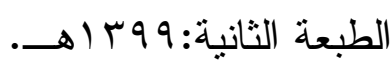

(OY):عون المعبود، تأليف: أبو الطيب محمد شمس الحق العظيم آبادي تحقيق: عبد الرحمن محمد عثمان، الناشر: المكتبة السلفية المدينة المنورة،

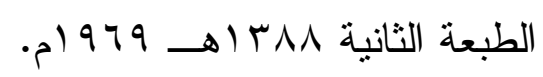
(ro): العين والأثر في عقائد أهل الأثر، تأليف: عبد الباقي بن عبد الباقي بن

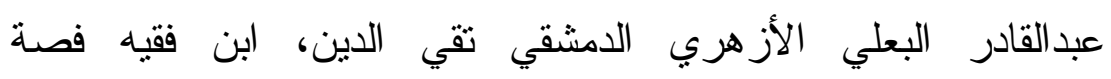

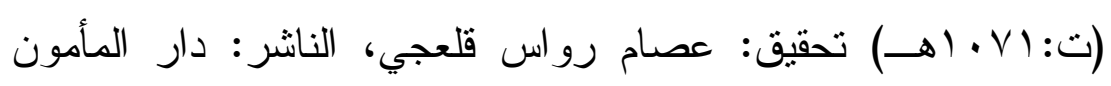
للتر اث الطبعة الأولى V. • أهـ. (ع (0): غذاء الألباب في شرح منظومة الآداب، نأليف: الثيخ محمد السفاريني

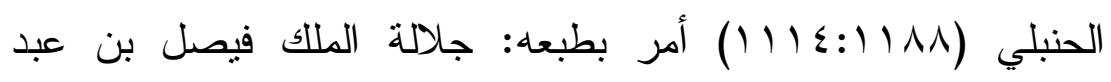
العزيز آل سعود، ملك المملكة العربية السعودية، مطبعة الحكومة بمكة. (00): الفروق، تأليف: أبو العباس شهاب الدين أحمد بن إدريس بن عبد

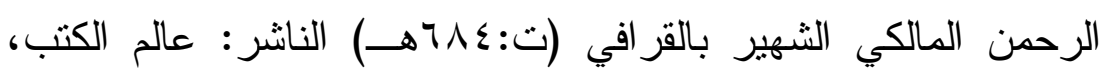

$$
\text { بدون الطبعة و التاريخ. }
$$

(7ه): الفتوى، (مجموع فتاوى) تأليف: عبد العزيز بن عبد الله بن عبد الرحمن ابن باز، جمع و اثر اف: د/محمد بن سعد السويعر ، طبع ونشر : رئاسة

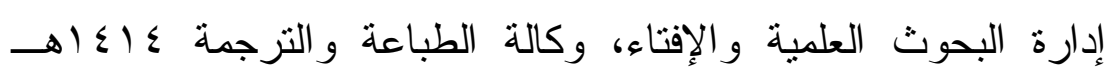
ب99 ام، الرياض، المملكة العربية السعودية. 


\section{الدكتور/ عبد الكريم بن إبراهيم آل غضية}

(OV): الفردوس، تأليف: أبي شجاع شيرويه بن شهردار بن شيرويه الديلمي

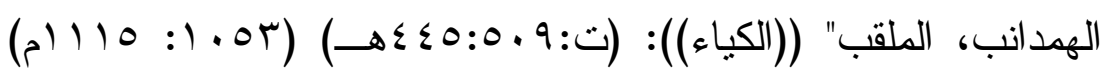
الطبعة الأولى، 7 • ؛ اهـ 9 أه ام: دار الكتب العلمية بيروت لبنان.

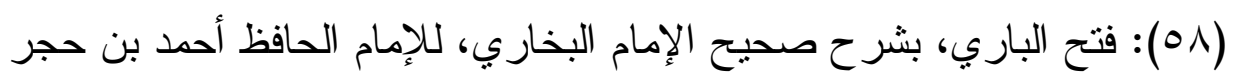
العسقلاني، تحقيق: عبد العزيز بن عبد الله ابن باز ومحب الدين

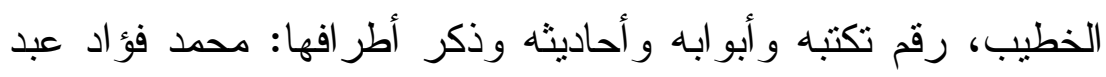
الباقي، طبعة دار الفكر مصور ا عن الطبعة السلفية (90): الفقه الإسلامي القضاء و الحسبة، تأليف: علي عبد القادر" مطبوع ضمن

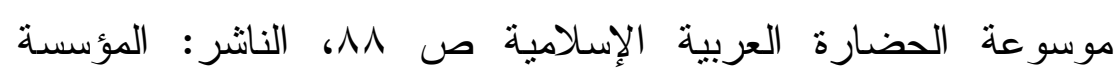

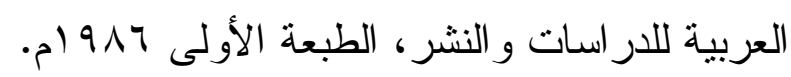
(•): كتاب المواقف، تأليف: عضد الدين عبد الرحمان بن أحمد الإيجي الناشر: دار الجيل: بيروت، تحقيق: د/عبد الرحمان عميرة الطبعة

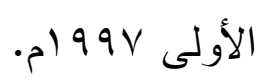

(1): الكامل في ضعفاء الرجال، تأليف:أبي أحمد بن عبد الله بن عدي الجرجاني، تحقيق: يحي مختار غزاوي، طبعة دار الفكر، بيروت،

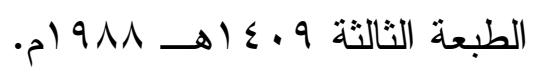

(YT): قو اعد الأحكام في مصالح الأنام، تأليف: أبو محمد عز الدين عبد العزيز بن عبد السلام بن أبي القاسم بن الحسن السلمي الدمشقي (ت: • .77هـ) راجعه و علق عليه: طه عبد الرؤوف سعد، الناشر: مكتبة الكليات

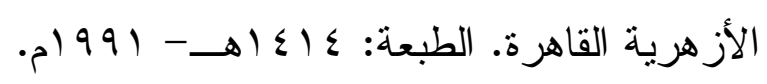

(TT): المحكم و المحيط الأعظم، تأليف: ابن سيدة، تحقيق: عبد الحميد هنداوي،

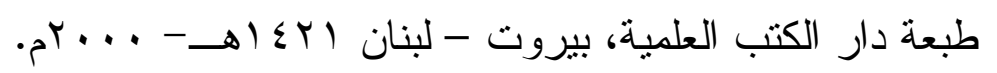




\section{عصاة المسلمين وعدابهم في ضوي الكتاب والسنة}

(ع 7): المصباح المنير في غريب شرح الكبير، تأليف: أحمد بن محمد بن علي

القيومي المقري، تحقيق: يوسف الثيخ محمد، طبعة المكتبة العصرية.

(10): الموسوعة الفقهية، صادر عن:وزارة الأوقاف و الثئون الإسلامية:

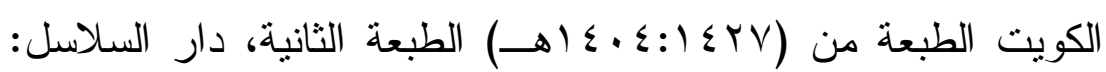

$$
\text { الكويت. }
$$

(T7): مسند الإمام أحمد بن حنبل أحمد الثيباني، (ت: إ؟هــ) تحقيق: شعيب

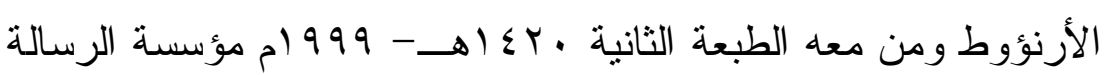

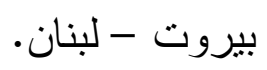

(TV): مستدرك علي الصحيحين، تأليف: أبي عبد الله محمد بن عبد الله بن محمد الحاكم النيسابوري (ت:0.ــهـ) مكتبة المطبوعات الإسلامية

$$
\text { حلب سوريا. }
$$

(71): المحرر الوجيز، تأليف: أبو محمد عبد الحق بن غالب بن عطية

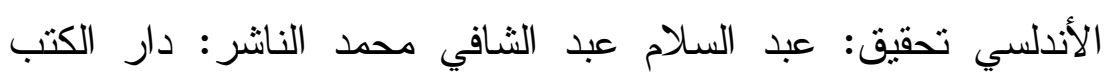

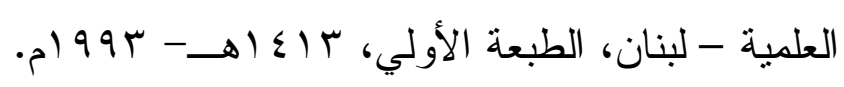

(97): معالم في السلوك وتذكية النفوس، تأليف: عبد العزيز بن محمد بن علي

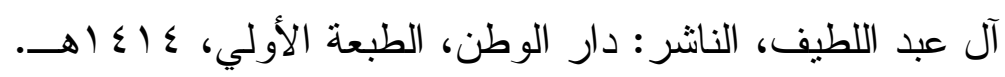

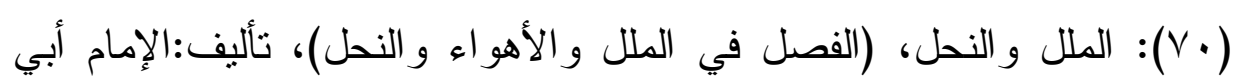

محمد علي بن أحمد بن حزم الطاهري (ت:07ءهـ) الطبعة الثانية

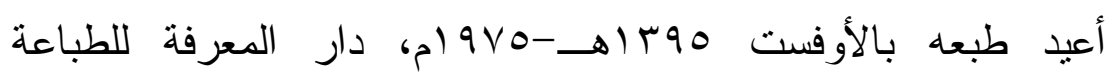

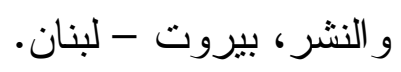




\section{الدكتور/ عبد الكريم بن إبراهيم آل غضية}

(V) ( مشكاة المصابيح، تأليف: محمد بن عبد الله الخطيب العمري، أبوعبد الله ولي الدين التبريزي (1ミاهـ) تحقيق: محمد ناصر الدين الألباني، الناشر : المكتب الإسلامي - بيروت، الطبعة الثالثة، 910 ام. (VY)

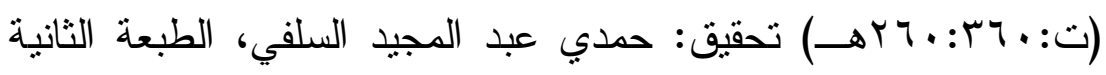

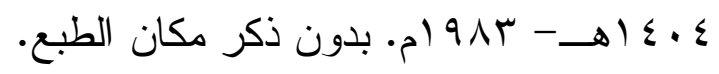

(VT)

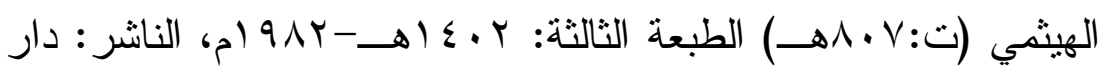

$$
\text { الكتاب العربي، بيروت: للبنان. }
$$

(V乏) الكوفي، تحقيق: كمال يوسف الحوت، مكتبة الرشد الرياض، الطبعة

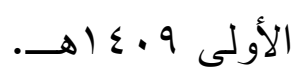

(Vo): معجم الصحابة، تأليف: أبو الحسين عبد الباقي بن قانع بن مرزوق بن

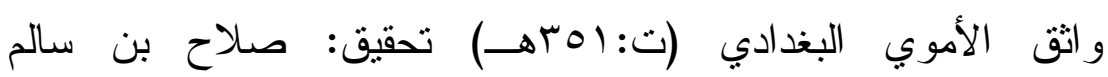
المصراتي الناشر: مكتبة الغرباء الأثرية: المدينة المنورة، الطبعة الهاتية

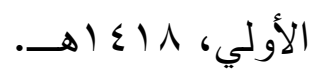

(VT)

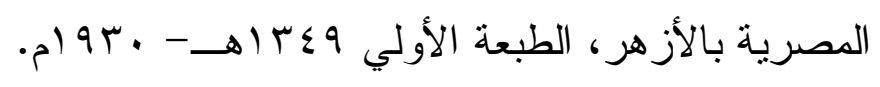

(VV)

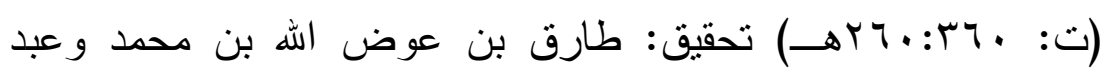
المحسن بن إبراهيم الحسيني، طبع عام 10؛ اهــ90-9 ام دار الحرمين للطباعة و النشر مصر و السودان. 
(V^)

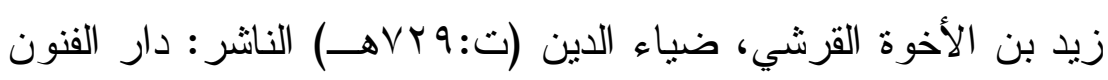

$$
\text { (كمبردج) }
$$

(V9): النهاية " في غريب الحديث و الأثر، للإمام مجد الدين أبي السعادات

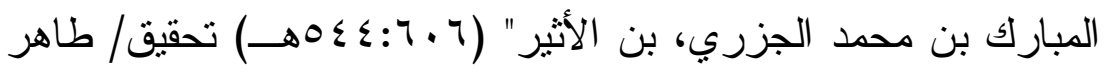
أحمد الزاوي، محمود محمد الطناحي، الناشر : المكتبة الإسلامية. (^): دلالة الأسماء الحسنى على التّزيه، إعداد: د/ عيسى بن عبد الله السيّعدي، كليّة التربية بالطائف قسم الدر اسات الإسلاميّة. 
فهــرس الآيــات

\begin{tabular}{|c|c|}
\hline |لصفحة & الآيــــة \\
\hline$\mu$ & 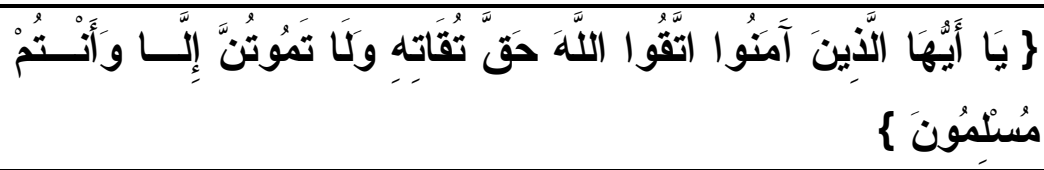 \\
\hline$r$ & 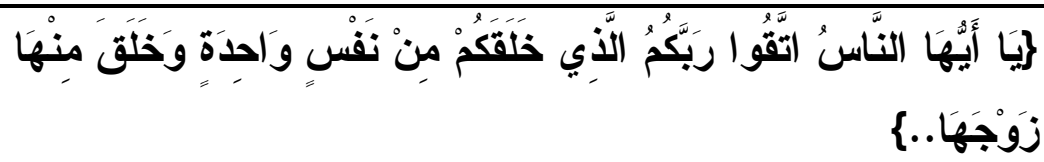 \\
\hline$r$ & 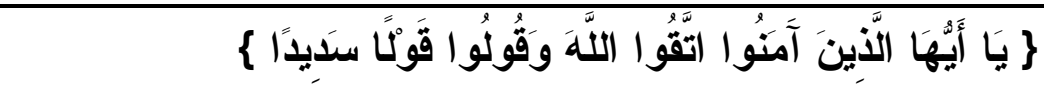 \\
\hline$r$ & 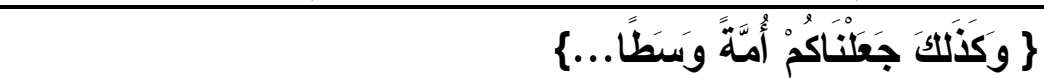 \\
\hline Ir & 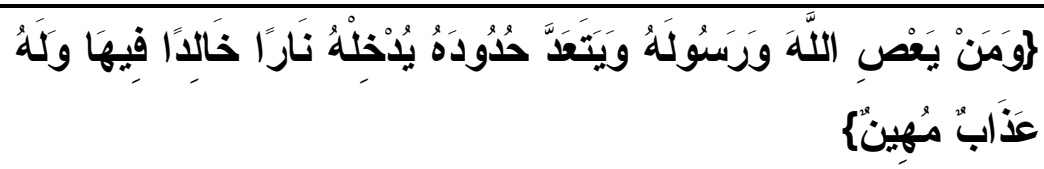 \\
\hline Ir & 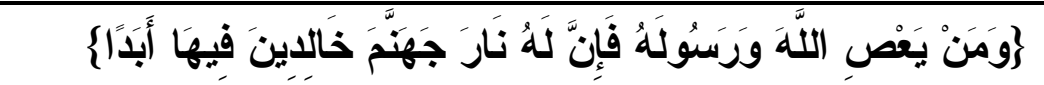 \\
\hline Ir & 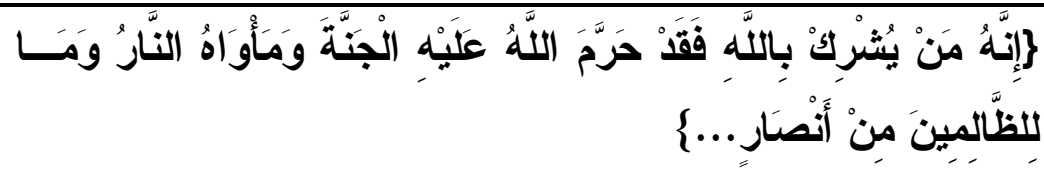 \\
\hline Ir & 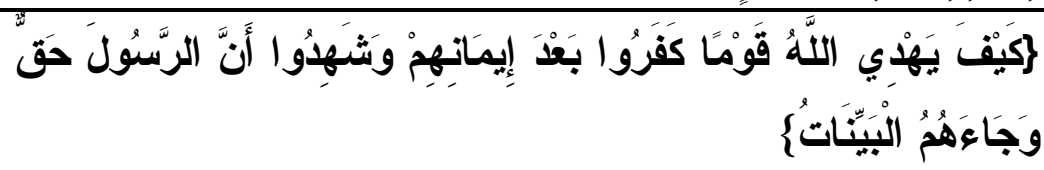 \\
\hline Ir & 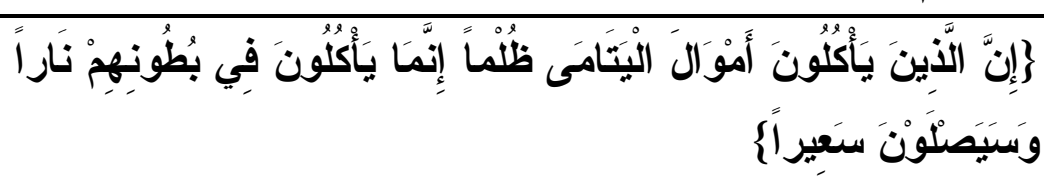 \\
\hline ir & 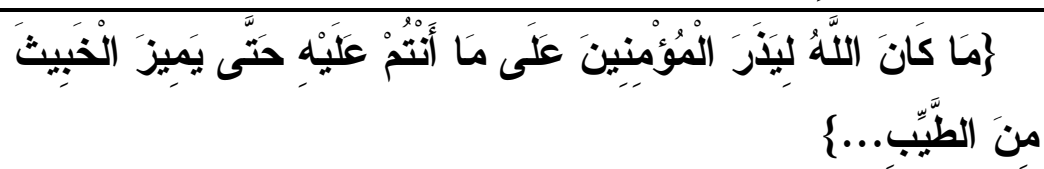 \\
\hline ir & 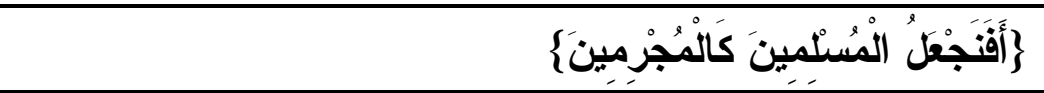 \\
\hline r & 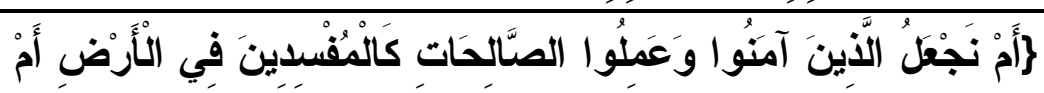 \\
\hline
\end{tabular}


عصاة السلمين وعدابهم في ضوي الكتاب والسنة

\begin{tabular}{|c|c|}
\hline & 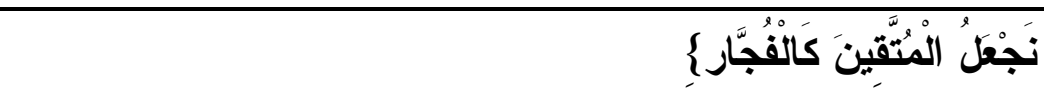 \\
\hline 17.10 & 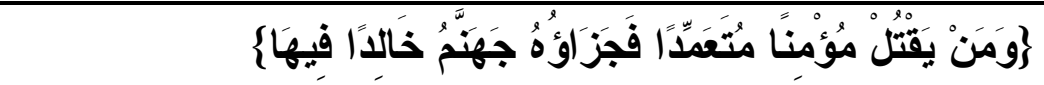 \\
\hline 18,10 & 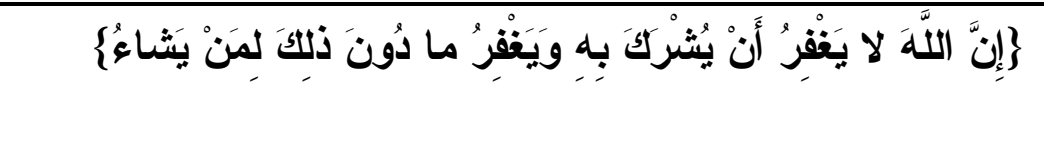 \\
\hline IV & 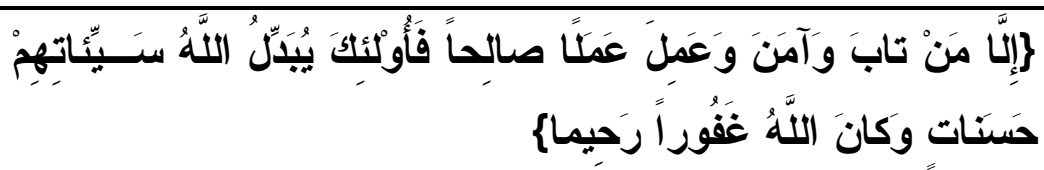 \\
\hline 11 & 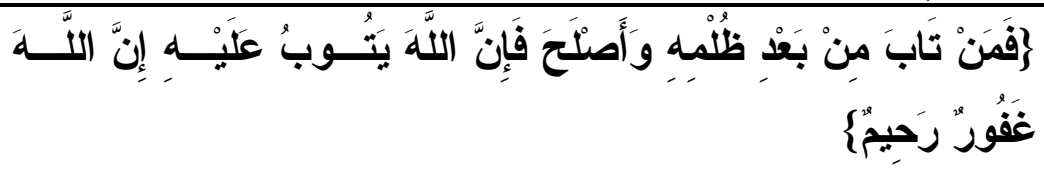 \\
\hline 11 & 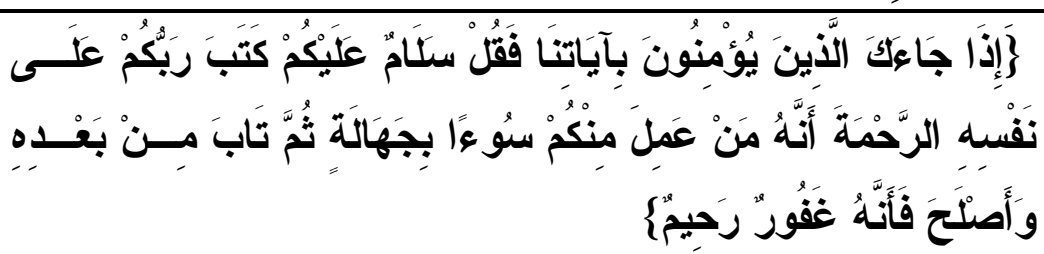 \\
\hline 19 & 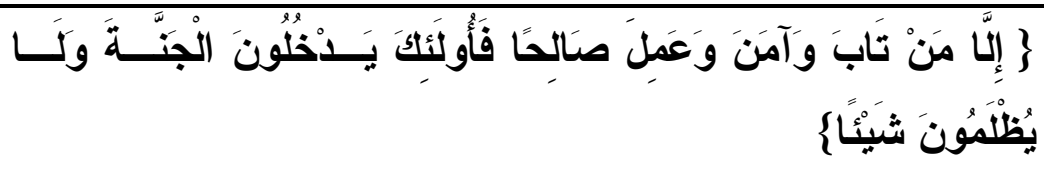 \\
\hline 19 & 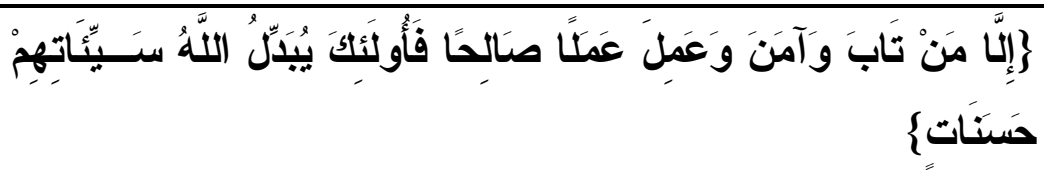 \\
\hline 19 & 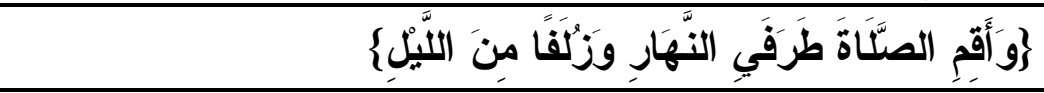 \\
\hline r & 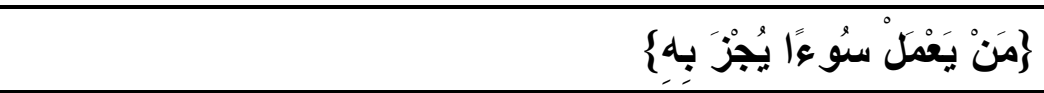 \\
\hline$r r$ & 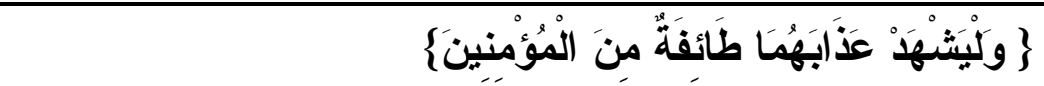 \\
\hline$r \varepsilon$ & 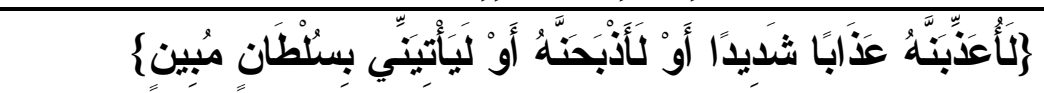 \\
\hline ro & 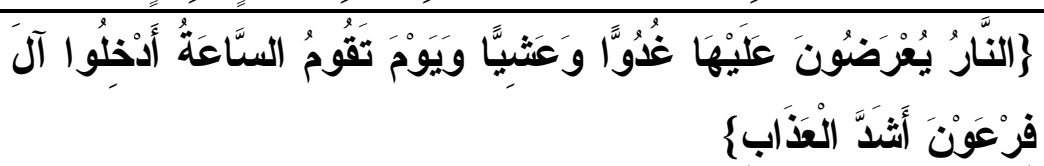 \\
\hline
\end{tabular}




\section{فهرس الأحاديث}

\begin{tabular}{|c|c|}
\hline |لصغهة & طرفع الحصيث الثريفع \\
\hline$\varepsilon$ & يسروا ولا تعسروا \\
\hline 10 & 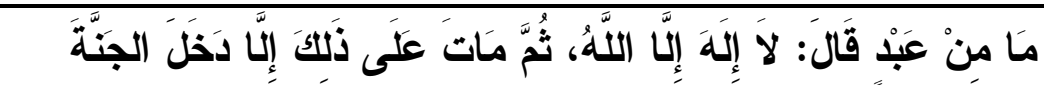 \\
\hline 17 & 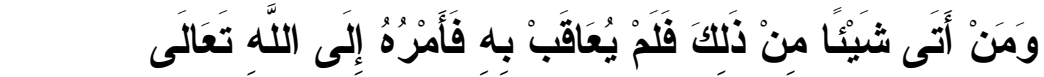 \\
\hline 11 & 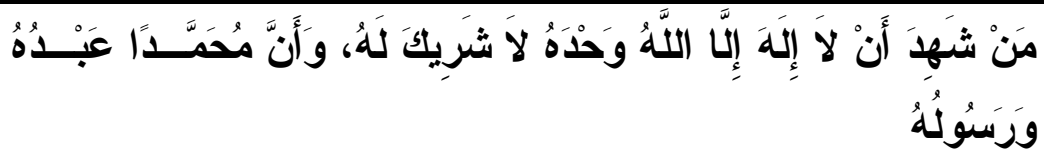 \\
\hline 19 & ما يُصِيبُ المُسنْمِ، مِنْ نَصَبِ وَلَا وَصَبِ، وَلَا هَمِ وَلَا حُزْنِ \\
\hline$r$. & 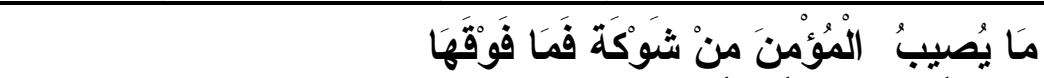 \\
\hline$r$. & 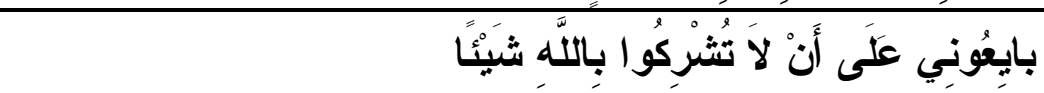 \\
\hline$r r$ & 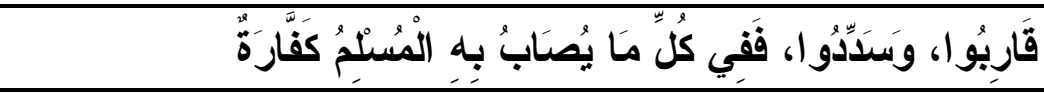 \\
\hline Tr & 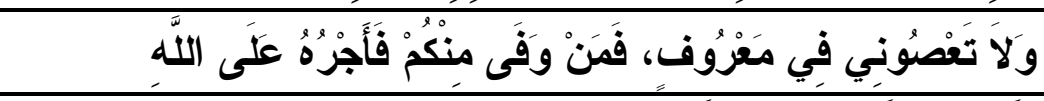 \\
\hline$Y Y$ & لَيَعَدَبَّانِ وَمَا يُعَدَّبَانِ مِنْ كَبِيرِ \\
\hline TV & تُفْتَنُ يَهُوُدُ \\
\hline$r \wedge$ & 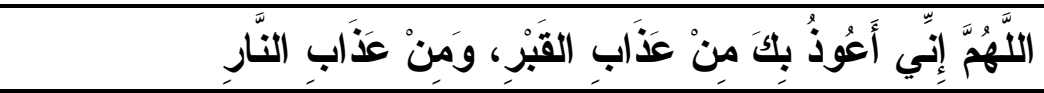 \\
\hline$r \wedge$ & 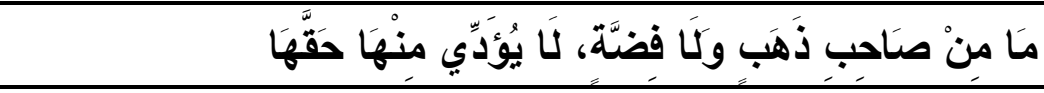 \\
\hline rq & يحشر المتكبرون أمثال الذر يوم القيامة \\
\hline r. & ثُوَّ يُؤْتَى بِالْجَسنْ فَيْجْعَلْ بَيْنَ ظَهْرَيْ جَهَنَّمَ \\
\hline r & 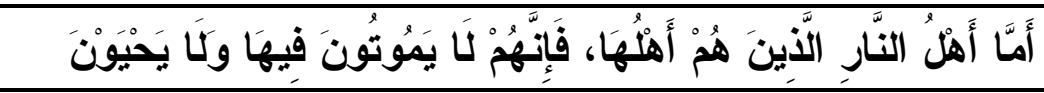 \\
\hline rr & 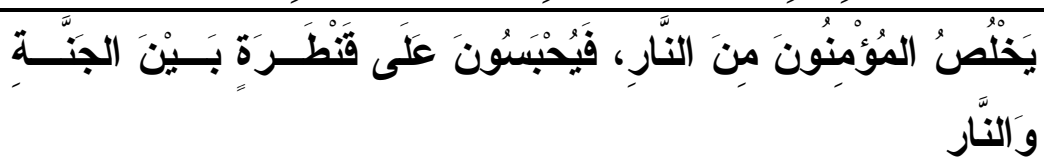 \\
\hline
\end{tabular}




\section{فهرس الموضوعات}

\begin{tabular}{|c|c|}
\hline |لص:مهنة & الهوذــوع \\
\hline r & 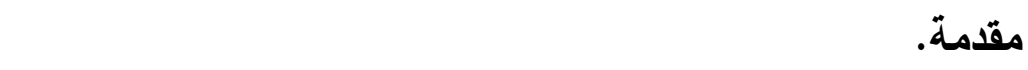 \\
\hline 9 & الفصل الأول: عصاة المسلمين، وفيه عدة مباحث. \\
\hline 11 & المبحث الأول: التعريف بـ (عصاة المسلمين). \\
\hline ir & المبحث الثاني: أدلة عذاب عصاة المسلمين. \\
\hline $1 \varepsilon$ & المبحث الثالث: منهج أهل السنة في عذاب عصاة أمة محمد (赔) \\
\hline 10 & المبحث الر ابع: موقف علماء السنة من نصوص الخلود. \\
\hline $1 \wedge$ & 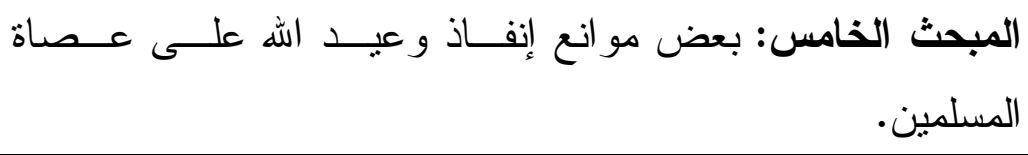 \\
\hline 11 & 1- النوحيد و الإخلاص لله تعالى. \\
\hline $1 \wedge$ & r- التوبة النصوح. \\
\hline 19 & ونحو ها. \\
\hline 19 & ع- الصبر و الاحتساب على المصائب و الابتلاءات. \\
\hline$r$. & 0- إقامة الحدود الشرعية في الدنيا. \\
\hline r & الفصل الثاني: أنواع عذاب عصساة المسلمين. \\
\hline$r r$ & أنواع عذاب عصاة المسلمين وينقسم إلى قسمين. \\
\hline$r r$ & القسم الأول: عذاب في الدنبا. \\
\hline rr & النوع الأول: الابتلاءات العامة و الخاصة. \\
\hline$r r$ & النوع الثاني: العقوبات الثر عية. \\
\hline
\end{tabular}


الدكتور/ عبد الكريم بن إبراهيم آل غضية

\begin{tabular}{|c|c|}
\hline$Y \varepsilon$ & القسم الثاني. \\
\hline ro & الصنف الأول: عذاب القبر . \\
\hline$r \wedge$ & حتى يقضى بين العبادي: العذاب بعد البعث - وقبل دخول الجنة أو النار - \\
\hline$r$. & 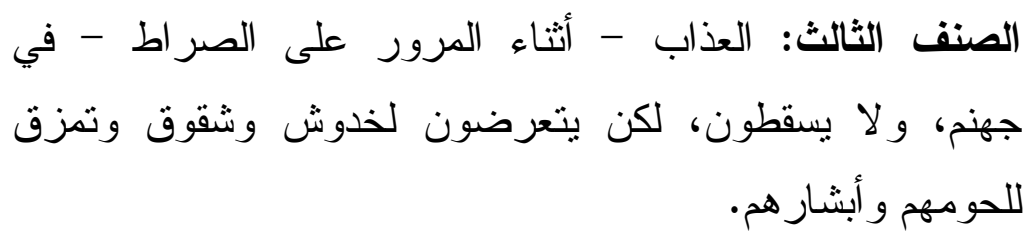 \\
\hline$r$. & الصنف الرابع: العذاب في جهنم. \\
\hline rr & (في القنف الخامس: العذاب بعد مجاوزة الصر اط وقبل دخول الجنة \\
\hline r & المر اجــــــع. \\
\hline$\leqslant 7$ & فهـــــرس الآيات. \\
\hline$\varepsilon \wedge$ & فهرس الأحاديث. \\
\hline$\leqslant 9$ & فهرس الموضوعات. \\
\hline
\end{tabular}

